\title{
Revisão do gênero Paramecocephala Benvegnú, 1968 (Heteroptera, Pentatomidae) ${ }^{1}$
}

\author{
Angélica Frey-da-Silva ${ }^{2}$ \\ Jocélia Grazia ${ }^{2}$ \\ José Antônio Marin Fernandes ${ }^{3}$
}

\begin{abstract}
Revision of the genus Paramecocephala Benvegnú, 1968 (Heteroptera, Pentatomidae). The Neotropical genus Paramecocephala Benvegnú, 1968 is revised based on morphological characters, particularly of the genitalia of both sexes. Formerly monobasic with $P$. foveata Benvegnú, 1968, type species, the genus received two species recently transferred from Mecocephala Dallas, 1851: M. fusca Haglund, 1868 and M. uruguayensis Pirán, 1970. Five new species are herein described: P. australis Frey-da-Silva \& Grazia sp. nov., P. bachmanni Frey-da-Silva \& Grazia sp. nov., P. bergrothi Frey-daSilva \& Grazia sp. nov., $P$. guianensis Frey-da-Silva \& Grazia sp. nov. and $P$. subsolana Frey-da-Silva \& Grazia sp. nov. Illustrations of the genitalia, a key to the species and a distribution map are provided.
\end{abstract}

KeYwords. Mecocephala; morphology of genitalia; Neotropical region; Pentatomini; taxonomy.

\section{INTRODUÇÃO}

HAGLund (1868) descreveu Tibraca fusca com base em um exemplar macho de procedência duvidosa, possivelmente do Brasil. STÅL (1872) citou, em sua monografia, o gênero Tibraca Stål, 1860, incluindo duas espécies conhecidas, sendo uma delas T. fusca. LethIERRY \& SEVERIN (1893) e KirKALDY (1909) também citaram as mesmas espécies em seus catálogos. BARBER (1941) citou T. fusca para a América do Sul. Lima (1947) considerou o gênero Ogmocoris Mayr, 1864 como sinônimo júnior de Tibraca incluindo nesse trabalho cinco espécies, entre elas T. fusca. Pirán (1967) designou como alótipo de Mecocephala rubripes Berg, 1894, um exemplar macho procedente de Pelotas (Rio Grande do Sul, Brasil). Benvegnú (1968) descreveu o gênero Paramecocephala, monotípico, com a espécie-tipo $P$. foveata Benvegnú, 1968, uma nova espécie, com base em um exemplar macho procedente de Belo Horizonte, Minas Gerais, Brasil. PIRÁN (1970) descreveu Mecocephala uruguayensis, uma nova espécie para a fauna da República do Uruguai, com base em três exemplares procedentes de Montevideo, Artigas e Treinta y Tres. Nesse trabalho o autor incluiu uma chave de identificação para as espécies do gênero Mecocephala Dallas, 1851. Fernandes \& Grazia (1998) revisaram o gênero Tibraca e transferiram T. fusca para o gênero Mecocephala. Nesse trabalho os autores incluíram uma chave de identificação para as espécies do gênero Tibraca. Finalmente, SCHWERTNer et al. (2002) revisaram o gênero Mecocephala e transferiram M. uruguayensis e M. fusca para Paramecocephala. O gênero Paramecocephala apresenta grande afinidade com Mecocephala Dallas, 1851 e Tibraca Stål, 1860. Neste trabalho são apresentadas as descrições detalhadas do gênero Paramecocephala e suas oito espécies: $P$. foveata Benvegnú, 1968, P. fusca (Haglund, 1868), P. uruguayensis (Pirán, 1970) e mais cinco novas espécies, com base em caracteres morfológicos gerais e da genitália de ambos os sexos.

Foram examinados 108 exemplares, incluindo os holótipos conhecidos pertencentes às coleções listadas a seguir, juntamente com os nomes dos curadores e/ou responsáveis pelo empréstimo. As siglas seguem ARNETT et al. (1993). BMNH - The Natural History Museum, Londres, Inglaterra (M. Webb); DEIC-Deutsches Entomologisches Institut, Eberswalde, Alemanha (E. K. Groll); DZUP - Coleção de Entomologia Pe. Jesus Santiago Moure, Departamento de Zoologia, Universidade Federal do Paraná, Curitiba, Brasil (L. Marinoni); IZAV - Instituto de Zoologia Agrícola, Universidad Central de Venezuela, Maracay, Venezuela (E. Osuna); MACN - Museo

1. Contribuição no 374 do Departamento de Zoologia da Universidade Federal do Rio Grande do Sul, Porto Alegre, RS. Dissertação apresentada ao Programa de Pós-graduação em Biologia Animal - UFRGS (Porto Alegre-RS) para obtenção do título de Mestre em Ciências Biológicas.

2. Universidade Federal do Rio Grande do Sul, Instituto de Biociências, Departamento de Zoologia, Prédio 43435. Av. Bento Gonçalves 9500, 91501-570 Porto Alegre-RS, Brasil. Bolsistas do CNPq. Endereço eletrônico: angelzi@zipmail.com.br; jocelia@ufrgs.br

3. Universidade Luterana do Brasil, Faculdade de Biologia. Rua Miguel Tostes 101, 92420-280 Canoas-RS, Brasil.

Endereço eletrônico: josefern@ufrgs.br 
Argentino de Ciencias Naturales "Bernardino Rivadavia", Buenos Aires, Argentina (A. Bachmann); MCNZ - Museu de Ciências Naturais, Fundação Zoobotânica do Rio Grande do Sul, Porto Alegre, Brasil (H. Gastal); MECB - Museu Entomológico Ceslau Biezanko, Pelotas, Brasil (E. J. Ely e Silva); MNHN - Museum National d' Histoire Naturelle, Paris, França (D. Pluôt); MNRJ - Museu Nacional da Universidade Federal do Rio de Janeiro, Rio Janeiro, Brasil (M. A. Monné); MPEG Museu Paraense Emílio Goeldi, Belém, Brasil (A. Harada); MZSP - Museu de Zoologia da Universidade de São Paulo, São Paulo, Brasil (F. DuVal); NHRS - Naturhistoriska Ricksmuseet, Sektionen für Entomologi, Estocolmo, Suécia (B. Viklund); RMNH - Nationaal Natuurhistorisch Museum Naturales, Leiden, Holanda (J. van Tol); UFRG - Departamento de Zoologia, Universidade Federal do Rio Grande do Sul, Porto Alegre, Brasil (J. Grazia); USNM - National Museum of Natural History, Washington, D. C., EUA (R. C. Froeschner).

Obtiveram-se 16 parâmetros morfométricos de cada exemplar: comprimento total, do ápice da cabeça até o ápice do VII segmento abdominal, em vista dorsal; comprimento da cabeça, da região ante-ocular, do pronoto e do escutelo ao longo da linha mediana longitudinal; largura da cabeça incluindo os olhos compostos; distância interocular ao nível dos olhos; largura do pronoto ao nível dos úmeros; largura do escutelo na base; largura abdominal ao nível do III urosternito; comprimento do cório; comprimento dos artículos antenais em vista dorsal, com exceção do primeiro, tomado em vista ventral. Para todos os parâmetros são fornecidos a média, valores mínimo e máximo e desvio padrão, para machos e fêmeas de cada espécie, com exceção do holótipo de $P$. foveata, no qual as medidas seguem BENVEGNú (1968). As medidas foram expressas em milímetros. O estudo da morfologia externa geral e da morfologia da genitália de ambos os sexos foi feito com o auxílio de câmara clara acoplada a estereomicroscópio. As peças da genitália interna de ambos os sexos foram clarificadas com $\mathrm{KOH}$ a $10 \%$, a frio, coradas com Vermelho Congo e mantidas em glicerina para observação e ilustrações, essas realizadas com auxílio de uma câmara clara, acoplada ao microscópio. A nomenclatura para as peças da genitália externa e interna seguiu Dupuis (1970) e GrAziA et al. (1999). A genitália interna de ambos os sexos das espécies $P$. bachmanni sp. nov.e $P$. guianensis sp. nov., genitália interna do macho (phallus) de P. fusca e genitália interna da fêmea de $P$. foveata não foram estudadas por se tratarem de exemplares únicos. A genitália interna do holótipo de $P$. foveata também não foi ilustrada por estar conservada em lâmina e lamínula permanente, já dissecada; foram aproveitadas as ilustrações de BENVEGNú (1968). A metodologia adotada para o exame, ilustração e descrição do material seguiu GrAZIA et al. (1999).

\section{Paramecocephala Benvegnú, 1968}

Paramecocephala Benvegnú, 1968: 87.

Espécie-tipo: Paramecocephala foveata Benvegnú, 1968, por monotipia.
Descrição. Tamanho variando de pequeno $(11,15 \mathrm{~mm})$ a grande (19,37 mm). Forma geral do corpo ovalada. Superfícies dorsal e ventral levemente convexas. Superfície dorsal do corpo densamente pontuada, pontuação profunda, negra a castanhoescura. Superfície ventral com pontuação negra. Pernas sem pontos, tíbias sulcadas dorsalmente.

Cabeça subtriangular, mais longa que larga, exceto em $P$. bachmanni Frey-da-Silva \& Grazia sp. nov., onde é mais larga que longa. Clípeo mais longo e mais elevado que as jugas, com ápice arredondado e intumescido, podendo ou não apresentar sulcos transversais dando a impressão de enrugamento. Região em "W" na base do clípeo sem pontos. Jugas defletidas e convergentes apicalmente; margens laterais sinuosas. Olhos castanhos a enegrecidos. Ocelos avermelhados. Tubérculo antenífero visível dorsalmente, com pequeno espinho dirigido lateralmente. Primeiro artículo antenal não ultrapassando o ápice da cabeça. Proporção dos artículos antenais: terceiro e quarto subiguais em comprimento, mais longos que o primeiro; esse mais longo que o segundo, sendo o quinto o mais longo de todos. Búculas evanescentes posteriormente. Rostro longo, ultrapassando em comprimento a margem posterior do IV urosternito, com exceção de $P$. bachmanni sp. nov. cujo rostro ultrapassa a margem posterior do III urosternito. Primeiro artículo do rostro não ultrapassando as búculas. Segundo artículo levemente achatado lateralmente. Pronoto trapezoidal, aproximadamente duas vezes e meia mais largo que longo entre os ângulos umerais. Declividade do pronoto variável nas espécies. Ângulos ântero-laterais em dente de ponta romba, dirigidos lateralmente, ultrapassando os olhos lateralmente. Margens ântero-laterais variando de sub-retilíneas a levemente côncavas, serrilhadas, crenuladas ou lisas. Margens pósterolaterais sinuosas e margem posterior sub-retilínea. Ângulos umerais não desenvolvidos, levemente intumecidos dorsalmente. Cicatrizes concolores; presença ou não de manchas calosas atrás das cicatrizes. Pontuação negra, densa e uniforme. Área evaporatória metapleural enegrecida, ocupando dois terços da largura da metapleura, estendendose até a mesopleura, não atingindo a margem lateral do tórax, levemente mais elevada que o terço lateral externo; esse, levemente intumescido. Mesosterno e metasterno recobertos por uma fileira longitudinal de pêlos brancos a dourados; mesosterno com uma carena mediana baixa; metasterno com sulco raso mediano. Ruga ostiolar clavada, com aproximadamente 1/3 da largura da metapleura. Escutelo com comprimento e largura subiguais. Ápice do escutelo arredondado, alcançando a margem anterior do V segmento do conexivo; margens laterais sinuosas. Base do escutelo com manchas calosas; ângulos basais apresentando pequenas escavações negras até fóveas profundas, excepcionalmente grandes em $P$. foveata. Cório atingindo a margem anterior do VI segmento do conexivo, uniformemente pontuado, com pontos menores e mais rasos que no restante do corpo. Calo do ápice da veia Rádio variando no tamanho e na cor. Membrana do hemiélitro castanhas. Conexivo exposto, concolor ou não ao corpo, com pontuação mais rasa do que no restante do corpo, 
concolor ou não. No limite do terço externo longitudinal dos segmentos do conexivo, presente um calo castanho a enegrecido. Ângulos póstero-laterais arredondados, não produzidos. Abdome ventralmente com sulco mediano raso, de extensão e coloração variadas. Margens látero-ventrais do abdome de coloração variada. Espiráculos enegrecidos, presentes do II ao VII urosternitos. Tricobótrios presentes do III ao VII urosternitos, situados um de cada lado da linha imaginária que tangencia os espiráculos, com exceção de $P$. foveata, onde os tricobótrios localizam-se externamente a esta linha. Região calosa presente em torno dos espiráculos.

Genitália do macho. Pigóforo de contorno quadrangular, cápsula genital globosa, abertura da taça genital dorsoposterior. Bordo dorsal (bd) escavado em diferentes graus. Terço mediano do bordo dorsal delimitado por pequenas concavidades (Fig. 14). Ângulos póstero-laterais escavados, arredondados ou agudos, levemente desenvolvidos. Bordo ventral (bv) subdividido em dois folhetos, um superior (fsbv) e outro inferior (fibv); folheto superior escavado ou não medianamente, projetando-se dorsalmente em 1+1 estruturas globosas, localizadas uma de cada lado do segmento X; folheto inferior projetado póstero-ventralmente, com ou sem projeções espiniformes medianas. Região do bordo ventral entre os folhetos superior e inferior variavelmente escavada, com estrias transversais dando a impressão de enrugamento. Segmento $\mathrm{X}$ (X) oval, ápice arredondado, com carena mediana dorsal subtriangular ou carena basal em "U”, como em P. guianensis sp. nov. Parâmeros muito reduzidos, geralmente encobertos pelas estruturas globosas formadas pelo folheto superior do bordo ventral. Phallus mais longo que largo, cilíndrico. Aparelho articular simples, com um par de conectivos dorsais (cd) curtos e processus capitati (pc) bem desenvolvidos. Phalloteca (ph) com 1+1 processos ventrais, medianos, mais curtos do que os processus conjuntivae 1 (prcj1). Conjuntiva (cj) bem desenvolvida com dois pares de processos: $1+1$ processus conjuntivae 1 ventrais, digitiformes, divergentes e curvados dorsalmente; $1+1$ processus conjuntivae 2 (prcj2) látero-dorsais com ápice esclerosado uni- a tri-ramificado, essa última ramificação correspondendo às intumescências da conjuntiva junto à base da vésica (v). Vésica membranosa, dorsalmente em forma de escudo e ventralmente em colar envolvendo a base do ductus seminis distalis (dsd), apicalmente projetada em $1+1$ pequenos processos. Ductus seminis distalis muito longo, helicoidal, dirigido ventralmente.

Genitália da fêmea. Placas genitais pontuadas. Gonocoxitos 8 convexos (gc8); bordo posterior e bordos suturais dos gonocoxitos 8 de forma variada, de acordo com a espécie; ângulos suturais arredondados, desenvolvidos ou não. Bordos posteriores dos laterotergitos 8 (la8) em ângulo agudo, arredondados ou sub-retilíneos, ultrapassando ou não em comprimento os laterotergitos 9 (la9). Laterotergitos 9 espatulares, ultrapassando a banda que une dorsalmente os laterotergitos 8. Segmento X (X) retangular. Gonocoxitos 9 (gc9) com margem anterior projetada em $1+1$ braços dirigidos anteriormente, atingindo ou ultrapassando a base dos laterotergitos 9. Gonapófises 9 (g9) com 1+1 espessamentos secundários em "L" invertido. Chitinellipsen (ch) presentes, com diâmetro subigual ou menor que o maior comprimento dos espessamentos secundários das gonapófises 9. Espessamento da íntima vaginal (eiv) subtriangular. Ductus receptaculi (dr) longo e fortemente enovelado na região posterior à área vesicular; região anterior também longa e ocasionalmente enovelada. Capsula seminalis (cs) arredondada, destituída de dentes, menor do que a pars intermedialis (pi). Crista anular anterior (caa) e crista anular posterior (cap) paralelas.

Comentários. Paramecocephala aproxima-se de Mecocephala e Tibraca. Paramecocephala compartilha com Mecocephala os seguintes caracteres: clípeo mais elevado que as jugas, rostro longo, presença do sulco abdominal e margens ântero-laterais do pronoto variáveis; e com Tibraca: metasterno com sulco raso mediano. Os três gêneros também apresentam relativa semelhança em relação à morfologia da genitália interna e externa de ambos os sexos. Paramecocephala distingue-se de Tibraca pela presença do sulco abdominal, e de Mecocephala, pelas seguintes características: comprimento da cabeça menor que uma vez e meia a largura da cabeça, margens laterais das jugas sinuosas, ângulos póstero-laterais do pigóforo escavados e gonocoxitos 8 fortemente convexos; em Mecocephala o comprimento da cabeça corresponde a pelo menos uma vez e meia a largura da cabeça, margens laterais das jugas sub-retilíneas, ângulos póstero-laterais do pigóforo não escavados e gonocoxitos 8 apenas levemente convexos.

Distribuição. O gênero Paramecocephala é exclusivamente neotropical, tendo seis espécies com registro no componente sudeste e apenas duas com registro no componente noroeste da Região Neotropical (AMORIM \& PiRes 1996). P. australis sp. nov., $P$. bachmanni sp. nov., $P$. bergrothi sp. nov. e $P$. uruguayensis (Pirán, 1970) estão restritas ao sul do Brasil, Uruguai e norte da Argentina. P. subsolana sp. nov., representada por apenas quatro exemplares procedentes da Bahia, Espírito Santo e São Paulo, tem sua distribuição provavelmente relacionada à Mata Atlântica. $P$. foveata Benvegnú, 1968 está representada por apenas dois exemplares, um de Minas Gerais e outro da Chapada dos Guimarães (Mato Grosso). Finalmente, $P$. fusca (Haglund, 1868) e P. guianensis sp. nov., que também estão representadas por um pequeno número de exemplares, com distribuição no componente norte amazônico (АMORIM \& PIREs 1996), sendo que P. fusca (Haglund, 1868) tem registro para o Suriname, Equador e Brasil, nos estados do Amazonas e Pará, e P. guianensis sp. nov. com registro na Guiana e Guiana Francesa (Figs. 1, 2).

\section{Chave para as espécies de Paramecocephala}

1. Cabeça mais longa do que larga; bordo posterior dos gonocoxitos 8 não formando um semicírculo ...............2

Cabeça mais larga que longa (Fig. 4); bordo posterior dos gonocoxitos 8 formando um semicírculo (Fig. 52) P. bachmannisp. nov. 
2(1). Rostro não ultrapassando o $\mathrm{V}$ urosternito ..................... 3 Rostro ultrapassando o V urosternito ..... 6

3(2). Laterotergitos 8 nitidamente projetados em ângulo agudo, ultrapassando, em muito, os laterotergitos 9 (Fig. 56). Segmento X do macho côncavo, com carena basal em "u"; folheto inferior do bordo ventral do pigóforo com nítidos espinhos muito próximos entre si (Fig. 15) P. guianensis sp. nov.

Laterotergitos 8 não desenvolvidos em ângulo agudo, porém podendo ultrapassar os laterotergitos 9 . Segmento $\mathrm{X}$ do macho com carena mediana subtriangular; folheto inferior do bordo ventral do pigóforo sem ou com projeções espiniformes, neste caso afastadas numa distância igual a largura do X segmento . ...4

4(3). Folheto inferior do bordo ventral do pigóforo destituído de espinhos (Fig. 11); bordo posterior dos gonocoxitos 8 sutilmente côncava no terço mediano (Fig. 51) .P. australis $\mathbf{S p . n o v . ~}$

Folheto inferior do bordo ventral do pigóforo com projeções espiniformes; bordo posterior dos gonocoxitos 8 sinuosa ou sub-retilínea ... 5

5(4). Estruturas globosas do folheto superior do bordo ventral do pigóforo curtas, alcançando a metade do segmento X e não encobrindo os parâmeros em vista dorsal (Fig. 14); bordo posterior dos laterotergitos 8 em ângulo agudo, pouco ultrapassando os laterotergitos 9, esses arredondados no ápice (Fig. 55) P. fusca (Haglund, 1868)

Estruturas globosas do folheto superior do bordo ventral do pigóforo longas, atingindo os processos dos ângulos basais do X segmento, encobrindo parcialmente os parâmeros em vista dorsal (Fig. 17); bordo posterior dos laterotergitos 8 sinuoso, subigual aos laterotergitos 9 em comprimento, estes subtruncados no ápice (Fig. 58) ....

. P. uruguayensis (Pirán, 1970)

6(2). Rostro atingindo o meio do VII urosternito; ângulos basais do escutelo com profundas fóveas negras P.foveata Benvegnú, 1968

Rostro alcançando o meio do VI urosternito; ângulos basais do escutelo com apenas pequenas escavações negras 7

7 (6). Coloração geral castanho-amarelada; pernas castanhas; margens laterais do abdome amareladas; placas genitais da fêmea castanhas, pontuação negra; bordo dorsal do pigóforo destituído de processos (Fig. 16) P. subsolana sp.nov.

Coloração geral castanho-avermelhada a ferrrugínea; pernas sanguíneas; abdome uniformemente ferrugíneo; margens laterais do abdome avermelhadas ou concolores; placas genitais da fêmea ferrugíneas, pontuação concolor; bordo dorsal do pigóforo com $1+1$ processos medianos enegrecidos projetados sobre a base do X segmento (Fig. 13) P. bergrothi $\mathbf{s p . ~ n o v . ~}$

Paramecocephala australis Frey-da-Silva \& Grazia, sp. nov. (Figs. 2, 3, 11, 18, 25, 32, 39, 43, 47, 51, 59)

Etimologia. O nome da espécie está relacionado à distribuição geográfica.

Macho. Medidas ( $\mathrm{n}=10)$ : comprimento total 13,66 (12,1914,70) 0,91; comprimento total da cabeça 2,52 (2,32-2,80) 0,15, largura 2,36 (2,24-2,40) 0,07; comprimento adiante dos olhos 1,67 (1,36-1,92) 0,17; distância interocular 1,43 (1,36-1,52) 0,06; comprimento do pronoto $2,79(2,48-2,96) 0,23$, largura $6,84(6,40-$ $7,04) 0,25$; comprimento do escutelo $4,95(4,48-5,28) 0,28$, largura $4,35(3,92-4,48)$ 0,20; largura abdominal 6,89 $(6,80-7,20) 0,32$; comprimento do cório $6,47(5,76-6,80) 0,35$; comprimento dos segmentos antenais: I $0,71(0,64-0,72) 0,03$; II $0,54(0,48-0,56)$ 0,03 ; III 1,23 (1,12-1,28) 0,04; IV 1,09 (1,04-1,12) 0,04; V 1,35 $(1,20-1,44) 0,08$.

Descrição. Cabeça levemente mais longa que larga (Fig. 3), castanho-avermelhada; pontuação negra, mais concentrada e confluente sobre as jugas. Superfície ventral castanho-escura a negra, densamente pontuada; pontuação concolor. Antenas castanho-escuras a negras. Rostro castanho, não ultrapassando a margem posterior do V urosternito. Pronoto castanho-avermelhado, nitidamente em declive na altura dos úmeros e em direção à cabeça. Pontos negros mais concentrados nas margens ântero- e póstero-laterais. Margens ântero-laterais do pronoto sub-retilíneas. Superfície ventral castanho-escura, pontuação negra. Áreas subcalosas amareladas próximas às procoxas, em áreas esparsas na margem anterior da mesopleura e margens laterais da metapleura. Peritrema ostiolar vermelho-alaranjado. Mesosterno e metasterno enegrecidos. Pernas castanho-avermelhadas. Presença ou não de pequenas áreas subcalosas amareladas na base do escutelo. Ângulos póstero-laterais do cório agudos, alcançando o meio do VI segmento do conexivo. Mancha calosa do ápice da veia Rádio pequena, esbranquiçada a amarelada. Sutura da membrana sub-retilínea. Conexivo concolor, densamente pontuado, pontos concolores. Ângulos pósterolaterais pouco pronunciados e arredondados. Superfície ventral do abdome castanho-escura a negra; margens laterais e sulco mediano castanho-alaranjados com pontuação negra. Nos exemplares mais escuros, as margens laterais e o sulco abdominal uniformemente escuros. Sulco mediano abdominal alcançando o VI urosternito. Pequenas manchas circulares negras nos ângulos ântero-laterais. Espiráculos negros. Base dos tricobótrios castanho-avermelhadas.

Genitália. Bordo dorsal do pigóforo (Fig. 11) côncavo medianamente. Ângulos póstero-laterais pouco escavados, arredondados. Carena do segmento $\mathrm{X}$ subtriangular, não 

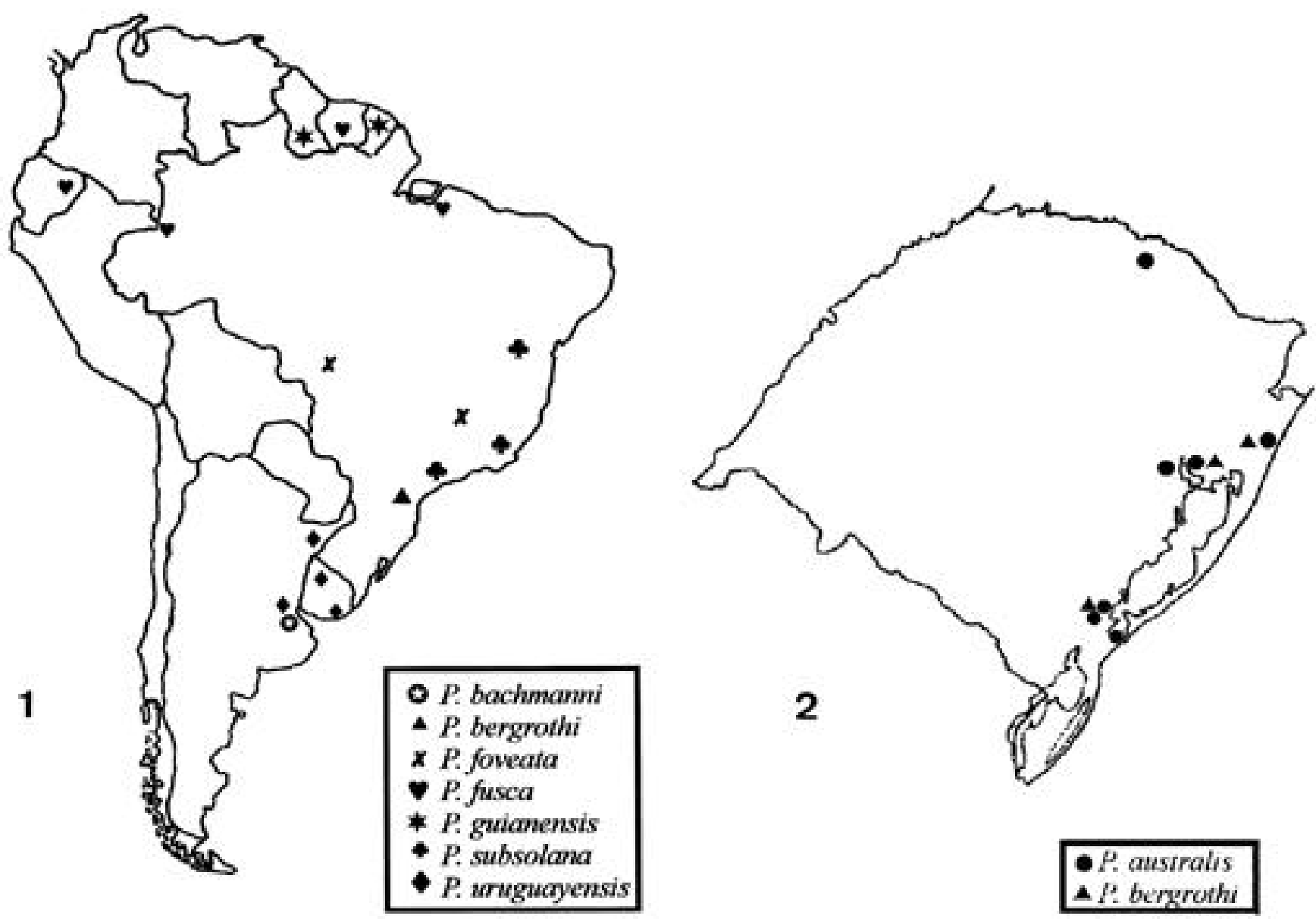

Figs. 1-2. Distribuição geográfica das espécies de Paramecocephala: 1, na América do Sul; 2, no Rio Grande do Sul, Brasil.

atingindo o ápice do segmento, com as áreas laterais à carena côncavas, pouco profundas; processos dos ângulos basais desenvolvidos e arredondados (Fig. 11). Folheto superior do bordo ventral levemente escavado medianamente em " $u$ ", estruturas globosas com ápice arredondado e produzido dorsolateralmente, base subtruncada e dirigida dorsalmente (Figs. 11, 25). Folheto inferior (Figs. 18, 25, 32) levemente escavado medianamente, destituído de projeções espiniformes. Parâmeros não visíveis em vista dorsal, encobertos pelas estruturas globosas do bordo ventral. Processos ventrais da phalloteca (Fig. 43) levemente divergentes e recurvados dorsalmente (Fig. 47), arredondados no ápice, mais largos e mais curtos do que os processus conjuntivae 1. Processus conjuntivae 1 curvados em direção dorsal; processus conjuntivae 2 direcionados dorsalmente, espatulares, superfície com ranhuras e ápice truncado (Figs. 39, 47).

Fêmea semelhante ao macho. Medidas $(\mathrm{n}=18)$ : comprimento total 14,58 (12,53-15,87) 0,70 ; comprimento total da cabeça 2,52 $(2,32-2,80) 0,15$; largura $2,36(2,24-2,40) 0,07$; comprimento adiante dos olhos 1,67 (1,36-1,92) 0,17; distância interocular
$1,43(1,36-1,52) 0,06$; comprimento do pronoto $2,79(2,48-2,96)$ 0,23 ; largura 6,84 (6,40-7,04) 0,25 ; comprimento do escutelo 5,12 $(4,48-5,36) 0,24$; largura 4,37 (4,00-4,80) 0,21 ; largura abdominal 6,96 (6,56-7,20) 0,23; comprimento do cório 6,59 (6,16-6,88) 0,21; comprimento dos segmentos antenais: I 0,72 $(0,64-0,80) 0,03$; II $0,55(0,48-0,64) 0,05 ;$ III $1,24(1,04-1,36) 0,08$; IV 1,13 $(1,04-1,28)$ 0,$06 ; \mathrm{V} 1,44(1,38-1,92) 0,22$.

Genitália (Figs. 51, 59). Placas genitais pontuadas; pontos enegrecidos e profundos. Disco dos gonocoxitos 8 levemente intumecido, castanho-escuro, com o bordo posterior sutilmente côncavo no terço mediano; ângulos suturais arredondados, não salientes, levemente divergentes. Bordos suturais dos gonocoxitos 8 subparalelos a ligeiramente divergentes no ápice. Laterotergitos $8 \mathrm{com}$ os bordos posteriores em ângulo reto, pouco ultrapassando os laterotergitos 9 em comprimento. Laterotergitos 9 espatulares, com ápice arredondado, pouco ultrapassando a banda que une dorsalmente os laterotergitos 8; margem interna com a metade apical sub-retilínea e metade basal levemente côncava e divergente; margem externa subretilínea. 

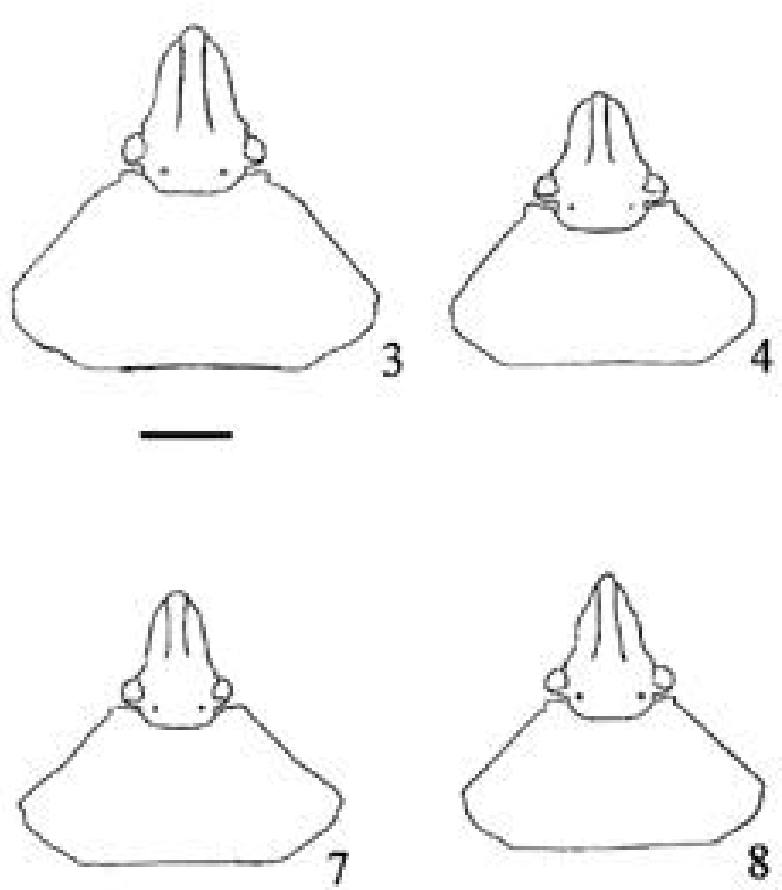

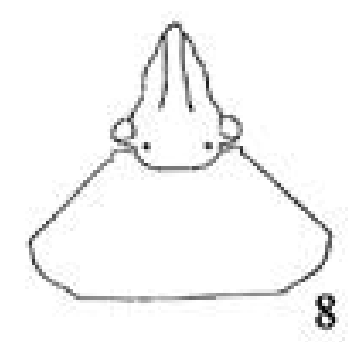

8
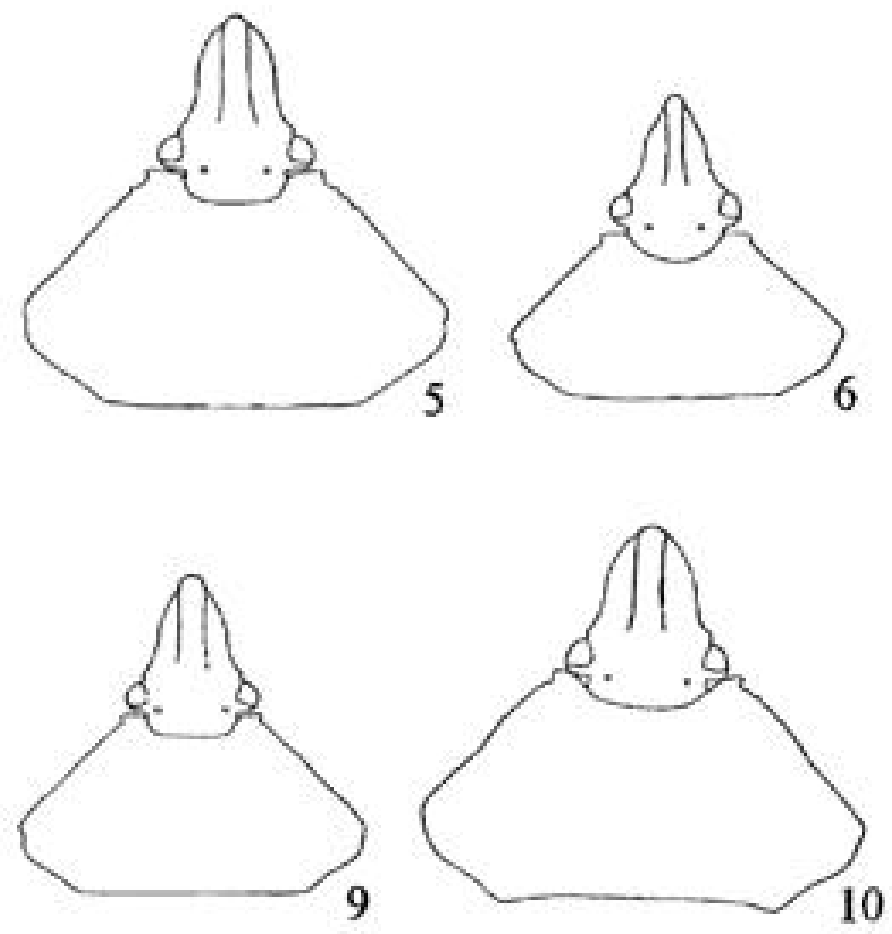

Figs. 3-10. Cabeça e pronoto. 3, Paramecocephala australis Frey-da-Silva \& Grazia sp. nov.; 4, Paramecocephala bachmanni Frey-da-Silva \& Grazia sp. nov.; 5, Paramecocephala bergrothi Frey-da-Silva \& Grazia sp. nov.; 6, Paramecocephala foveata Benvegnú, 1968; 7, Paramecocephala fusca (Haglund, 1868); 8, Paramecocephala guianensis Frey-da-Silva \& Grazia sp. nov.; 9, Paramecocephala subsolana Frey-da-Silva \& Grazia sp. nov.; 10, Paramecocephala uruguayensis (Pirán, 1970); escala $=2 \mathrm{~mm}$.

Material-tipo: Holótipo macho. BRASIL. Rio Grande do Sul: Porto Alegre, VI. 1986, J. Grazia leg. (MCNZ). Alótipo fêmea. BRASIL. Rio Grande do Sul: Eldorado do Sul, Fazenda Minuano, 16. VIII. 1989, U. Anner leg. (UFRG). Parátipos. Santa Catarina: Imbituba, 1 fêmea, II. 1994, L. A. Campos leg. (UFRG). Rio Grande do Sul: São José do Ouro, 1 macho, XI. 1996, E. Tolardo leg. (MECB); Imbé: Santa Terezinha, 1 fêmea, 16. II. 1973, M. H. Galileo leg. (MCNZ); Eldorado do Sul, 1 fêmea, 17. IX. 1992, J. A. M. Fernandes leg. (UFRG); Porto Alegre, 1 fêmea, 11. VI. 1952 (MCNZ); Pelotas, 1 macho, VII. 1986, M. Carissimi leg., 1 fêmea, X. 1986, Sérgio S. leg., 1 fêmea, IX. 1996, P. Pivota leg. (DZUP), 1 macho, III. 1991, Schneider leg., 1 macho, 4. IV. 1986, J. Luis leg., 1 fêmea, VI. 1991, R. Padilha leg., 1 fêmea, 13. XI. 1961, Mauri leg. (UFRG), 1 macho, 28. X. 1986, L. Kamopp leg., 1 fêmea, 5. VI. 1986, Azambuja leg., 1 fêmea, 20. XI. 1993, Vaziv leg. (MECB); Capão do Leão, 1 fêmea, 5. X. 1997, R. Rotta leg. (MECB); Rio Grande, Taim, 1 macho, 17. X. 1976, C. J. Becker leg. (MCNZ), 1 fêmea, 23. III3. IV. 1981, J. Grazia leg. (UFRG).

Comentários. Essa espécie, pela coloração e porte, aproximase de $P$. uruguayensis e $P$. bergrothi sp. nov. Distingue-se de ambas por ser de menor tamanho e pela ausência de projeções espiniformes no folheto inferior do bordo ventral do pigóforo. Pelo comprimento do rostro atingindo o $\mathrm{V}$ urosternito, se compara a $P$. uruguayensis, sendo que em $P$. bergrothi $\mathbf{s p . ~ n o v . ~}$ o rostro atinge o meio do VI urosternito.

Paramecocephala bachmanni Frey-da-Silva \& Grazia,sp.nov. (Figs. 1,4, 12, 19, 26, 33, 52)

Etimologia. O nome da espécie é uma homenagem ao coletor, Dr.
Alex O. Bachmann, entomólogo do Museo Argentino de Ciencias Naturales "Bernardino Rivadavia".

Macho. Medidas $(n=1)$ : comprimento total 12,30; comprimento total da cabeça 2,19; largura 2,51; comprimento adiante dos olhos 1,38; distância interocular 1,54; comprimento do pronoto 2,19; largura 5,91; comprimento do escutelo 4,46; largura 3,89; largura abdominal 6,32; comprimento do cório 5,83; comprimento dos segmentos antenais: I 0,65; II 0,49; III 1,22; IV 1,05; V 1,38.

Descrição. Cabeça mais larga que longa (Fig. 4), castanhoamarelada, pontuação densa e negra. Superfície ventral castanho-escura, pontuação densa e negra. Antenas castanhoescuras. Rostro castanho-escuro, ultrapassando a margem posterior do III urosternito. Pronoto castanho-amarelado, com pouco declive na altura dos úmeros em direção à cabeça. Pontuação do pronoto negra, mais concentrada e confluente no terço anterior. Margens ântero-laterais sub-retilíneas, levemente crenuladas no terço basal. Presença de 1+1 manchas calosas amareladas atrás das cicatrizes. Superfície ventral castanho-avermelhada a castanho-amarelada, densamente pontuada, pontuação enegrecida. Peritrema ostiolar castanhoamarelado. Mesosterno e metasterno enegrecidos. Pernas castanho-amareladas. Ângulos póstero-laterais do cório agudos, ultrapassando a margem anterior do $\mathrm{V}$ segmento do conexivo. Mancha calosa do ápice da veia Rádio pequena, concolor. Sutura da membrana sinuosa. Conexivo castanho- 

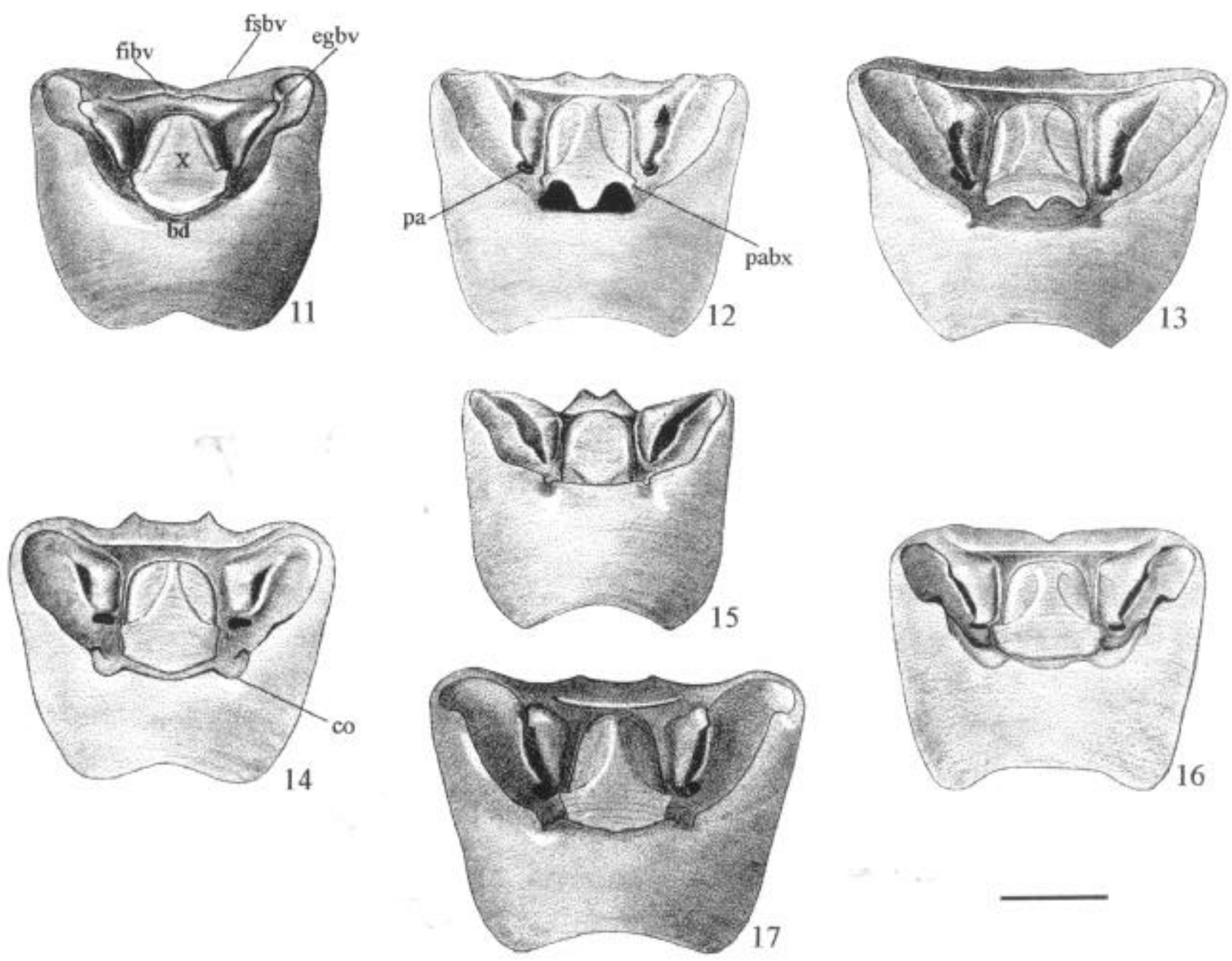

Figs. 11-17. Pigóforo, vista dorsal. 11, Paramecocephala australis Frey-da-Silva \& Grazia sp. nov.; 12, Paramecocephala bachmanni Frey-daSilva \& Grazia sp. nov.; 13, Paramecocephala bergrothi Frey-da-Silva \& Grazia sp. nov.; 14, Paramecocephala fusca (Haglund, 1868); 15, Paramecocephala guianensis Frey-da-Silva \& Grazia sp. nov.; 16, Paramecocephala subsolana Frey-da-Silva \& Grazia sp. nov.; 17, Paramecocephala uruguayensis (Pirán, 1970); $(\mathrm{bd}=$ bordo dorsal; $c 0=$ concavidade; egbv = espessamentos globosos do bordo ventral; fsbv = folheto superior do bordo ventral; fibv $=$ folheto inferior do bordo ventral; $\mathrm{pa}=$ parâmero; pabx = processo do ângulo basal do décimo segmento; $\mathrm{X}=$ décimo segmento; escala $=1 \mathrm{~mm}$.

claro, pontuação castanha a concolor. Superfície ventral do abdome castanho-avermelhada, margens laterais com uma faixa larga castanho-alaranjada, pontuação negra. Sulco mediano abdominal concolor, alcançando a metade do VI urosternito. Ângulos ântero-laterais do conexivo com pequenas manchas circulares castanho-escuras. Espiráculos negros. Base dos tricobótrios castanho-alaranjada.

Genitália. Bordo dorsal do pigóforo (Fig. 12) com 1+1 processos medianos, enegrecidos, projetados sobre a base do segmento X. Ângulos póstero-laterais fortemente escavados, pouco projetados, arredondados. Carena do segmento $\mathrm{X}$ subtriangular, áreas laterais à carena profundamente côncavas; processos dos ângulos basais desenvolvidos e subtruncados (Fig. 12). Folheto superior do bordo ventral sub-retilíneo medianamente, estruturas globosas mais estreitas, com ápice projetado lateralmente, enegrecido (Fig. 12). Folheto inferior (Figs. 19, 26, 33) com 1+1 suaves elevações medianas, não formando projeções espiniformes. Parâmeros pouco visíveis em vista dorsal.

Fêmea semelhante ao macho. Medidas $(\mathrm{n}=1)$ : comprimento total 12,63; comprimento total da cabeça 2,27; largura 2,43; comprimento adiante dos olhos 1,46; distância interocular 1,54; comprimento do pronoto 2,27 ; largura 6,08 ; comprimento do escutelo 4,78; largura 4,05; largura abdominal 6,48; comprimento do cório 6,16; comprimento dos segmentos antenais: I 0,65; os demais faltam.

Genitália (Fig. 52). Gonocoxitos 8 inflados, subtriangulares, 

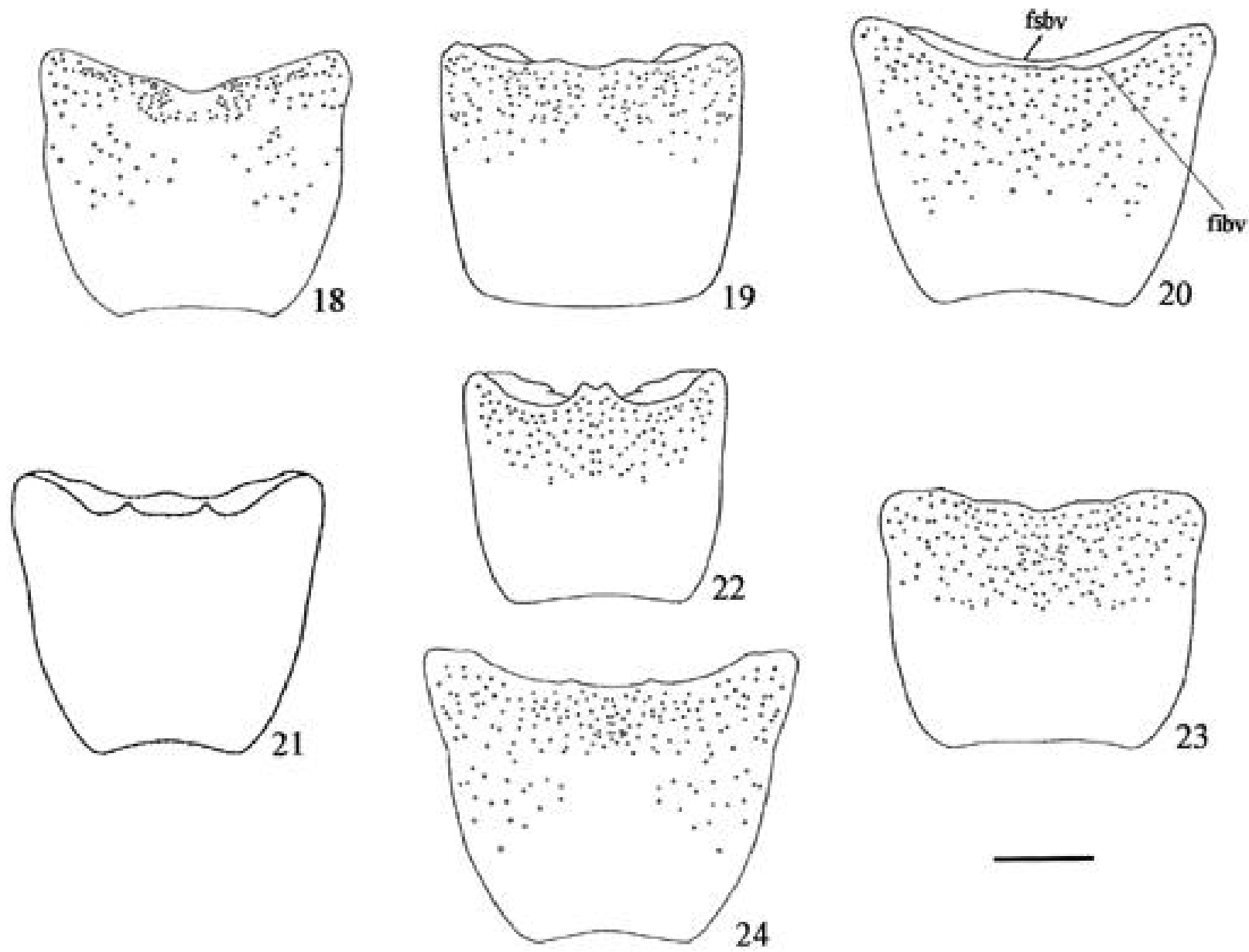

Figs. 18-24. Pigóforo, vista ventral. 18, Paramecocephala australis Frey-da-Silva \& Grazia sp. nov.; 19, Paramecocephala bachmanni Frey-daSilva \& Grazia sp. nov.; 20, Paramecocephala bergrothi Frey-da-Silva \& Grazia sp. nov.; 21, Paramecocephala fusca (Haglund, 1868); 22, Paramecocephala guianensis Frey-da-Silva \& Grazia sp. nov.; 23, Paramecocephala subsolana Frey-da-Silva \& Grazia sp. nov.; 24, Paramecocephala uruguayensis (Pirán, 1970); fsbv = folheto superior do bordo ventral; fibv = folheto inferior do bordo ventral; escala = $1 \mathrm{~mm}$.

com o bordo posterior convexo, juntos formando um semicírculo; bordos suturais paralelos, ângulos suturais não produzidos. Laterotergitos 8 com os bordos posteriores subretilíneos, subiguais em comprimento aos laterotergitos 9 . Laterotergitos 9 com ápice subtruncado, ultrapassando levemente a banda que une dorsalmente os laterotergitos 8; margem interna levemente côncava na metade basal, margem externa convexa.

Material-tipo. Holótipo macho. ARGENTINA. Buenos Aires: Gral. Alvarado, Miramar, 20. XI. 1946, Bachmann leg. (MACN). Alótipo fêmea. ARGENTINA. Buenos Aires, Bachmann leg. (MCNZ).

Comentários. Essa espécie, pelo porte e coloração, aproximase de $P$. subsolana $\mathbf{~ s p . ~ n o v . , ~ d a ~ q u a l ~ s e ~ d i s t i n g u e ~ p e l a ~ c a b e c ̧ a ~ e ~}$ comprimento do rostro. Nessa espécie a cabeça é mais larga do que longa e o rostro não ultrapassa a margem posterior do III urosternito; em P. subsolana $\mathbf{s p . ~ n o v . ~ a ~ c a b e c ̧ a ~ e ́ ~ m a i s ~ l o n g a ~ q u e ~}$ larga e o rostro atinge o meio do VI urosternito.
Paramecocephala bergrothi Frey-da-Silva \& Grazia, sp. nov. (Figs. 1, 2, 5, 13, 20, 27, 34, 40, 44, 48, 53, 60)

Mecocephala rubripes; Pirán, 1967: 21 (non Berg, 1894:18; Schwertner, Grazia \& Fernandes, 2002:

Etimologia. O nome da espécie é uma homenagem ao heteropterólogo Ernest E. Bergroth.

Macho. Medidas ( $\mathrm{n}=13)$ : comprimento total 16,60 (15,2517,55) 0,74 ; comprimento total da cabeça $3,19(2,92-3,65) 0,20$; largura 2,84 (2,67-2,92) 0,07; comprimento adiante dos olhos 2,11 (1,78-2,27) 0,12; distância interocular $1,75(1,62-1,86) 0,07$; comprimento do pronoto $3,31(3,00-3,48) 0,14$; largura 7,97 (7,37$8,34) 0,32$; comprimento do escutelo $6,09(5,59-6,48) 0,24$; largura $4,97(4,70-5,27) 0,13$; largura abdominal $8,22(7,29-8,83) 0,45$; comprimento do cório 7,98 (7,45-8,51) 0,30; comprimento dos segmentos antenais: I $0,90(0,73-0,97) 0,06$; II $0,57(0,49-0,65)$ 0,05 ; III 1,65 (1,46-1,86) 0,14; IV 1,47 (1,30-1,70) 0,17; V 1,76 $(1,62-1,86) 0,10$. 

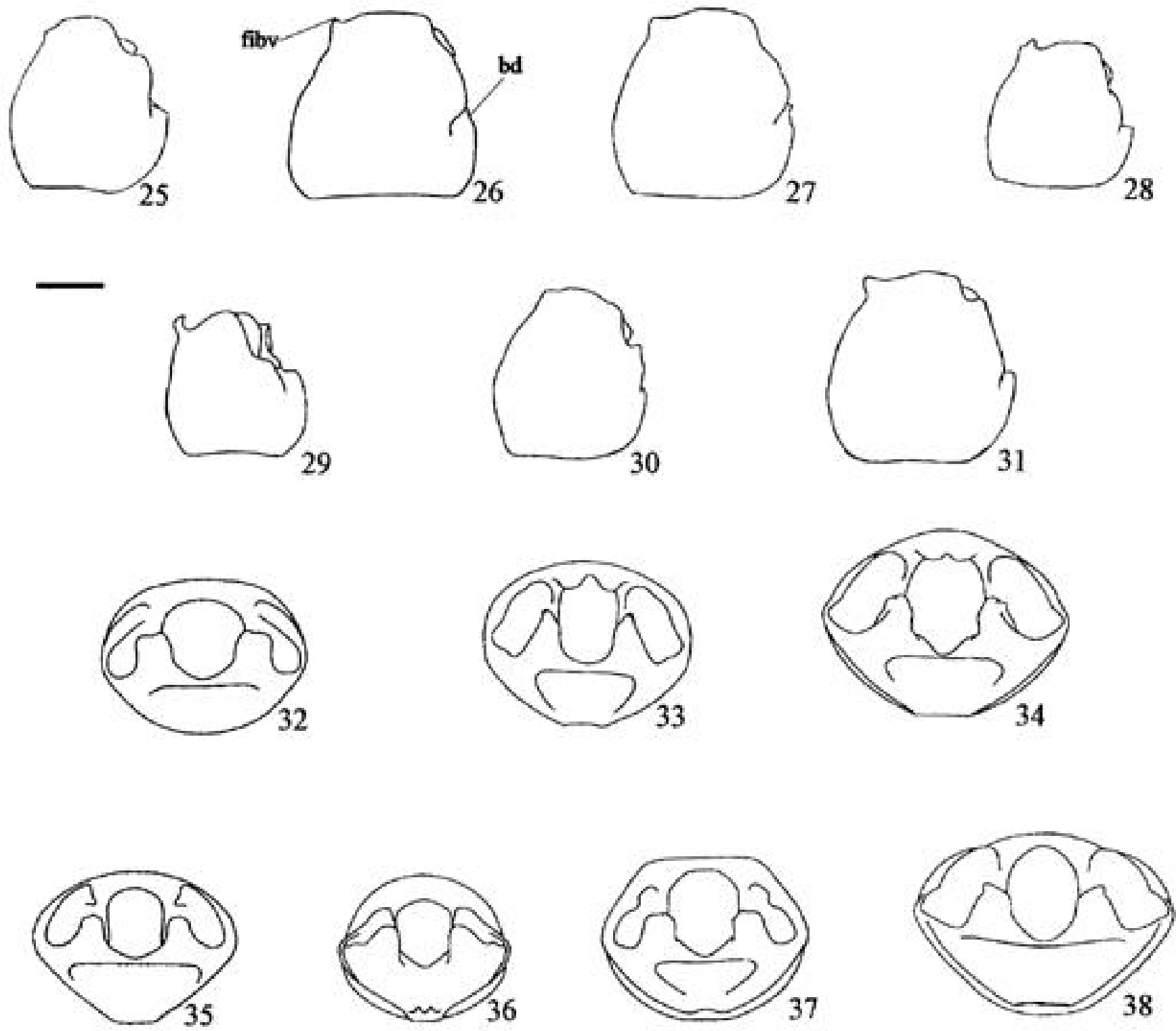

Figs. 25-38. Pigóforo: 25-31 vista lateral, 32-38 vista posterior, respectivamente. 25, 32, Paramecocephala australis Frey-da-Silva \& Grazia sp. nov.; 26, 33, Paramecocephala bachmanni Frey-da-Silva \& Grazia sp. nov.; 27, 34, Paramecocephala bergrothi Frey-da-Silva \& Grazia sp. nov.; 28, 35, Paramecocephala fusca (Haglund, 1868); 29, 36, Paramecocephala guianensis Frey-da-Silva \& Grazia sp. nov.; 30, 37, Paramecocephala subsolana Frey-da-Silva \& Grazia sp. nov.; 31, 38, Paramecocephala uruguayensis (Pirán, 1970); bd = bordo dorsal; fibv = folheto inferior do bordo ventral; escala $=1 \mathrm{~mm}$.

Descrição. Cabeça mais longa que larga (Fig. 5), castanhoavermelhada, pontuação negra. Superfície ventral enegrecida a castanho-avermelhada, com densa pontuação negra. Antenas castanho-avermelhadas. Rostro vermelho-alaranjado, ultrapassando o meio do VI urosternito. Pronoto castanhoavermelhado a castanho-amarelado, levemente declivente na altura dos úmeros em direção à cabeça; pontuação negra. Margens ântero-laterais sub-retilíneas, levemente crenuladas; 1+1 manchas calosas pequenas e amareladas atrás das cicatrizes. Superfície ventral castanho-avermelhada, pontuação negra. Áreas subcalosas alaranjadas anteriores às procoxas.
Peritrema ostiolar vermelho-alaranjado. Mesosterno e metasterno enegrecidos. Pernas sanguíneas. Presença de áreas calosas avermelhadas na base do escutelo. Ângulos pósterolaterais do cório arredondados, ultrapassando a margem anterior do VI segmento do conexivo. Mancha calosa no ápice da veia Rádio grande, esbranquiçada. Sutura da membrana sinuosa. Conexivo concolor, densamente pontuado, pontos negros. Ângulos póstero-laterais pouco pronunciados, arredondados. Superfície ventral do abdome ferrugínea, sulco mediano avermelhado, alcançando a margem posterior do $\mathrm{V}$ urosternito; pontuação negra. Espiráculos negros. Base dos tricobótrios 

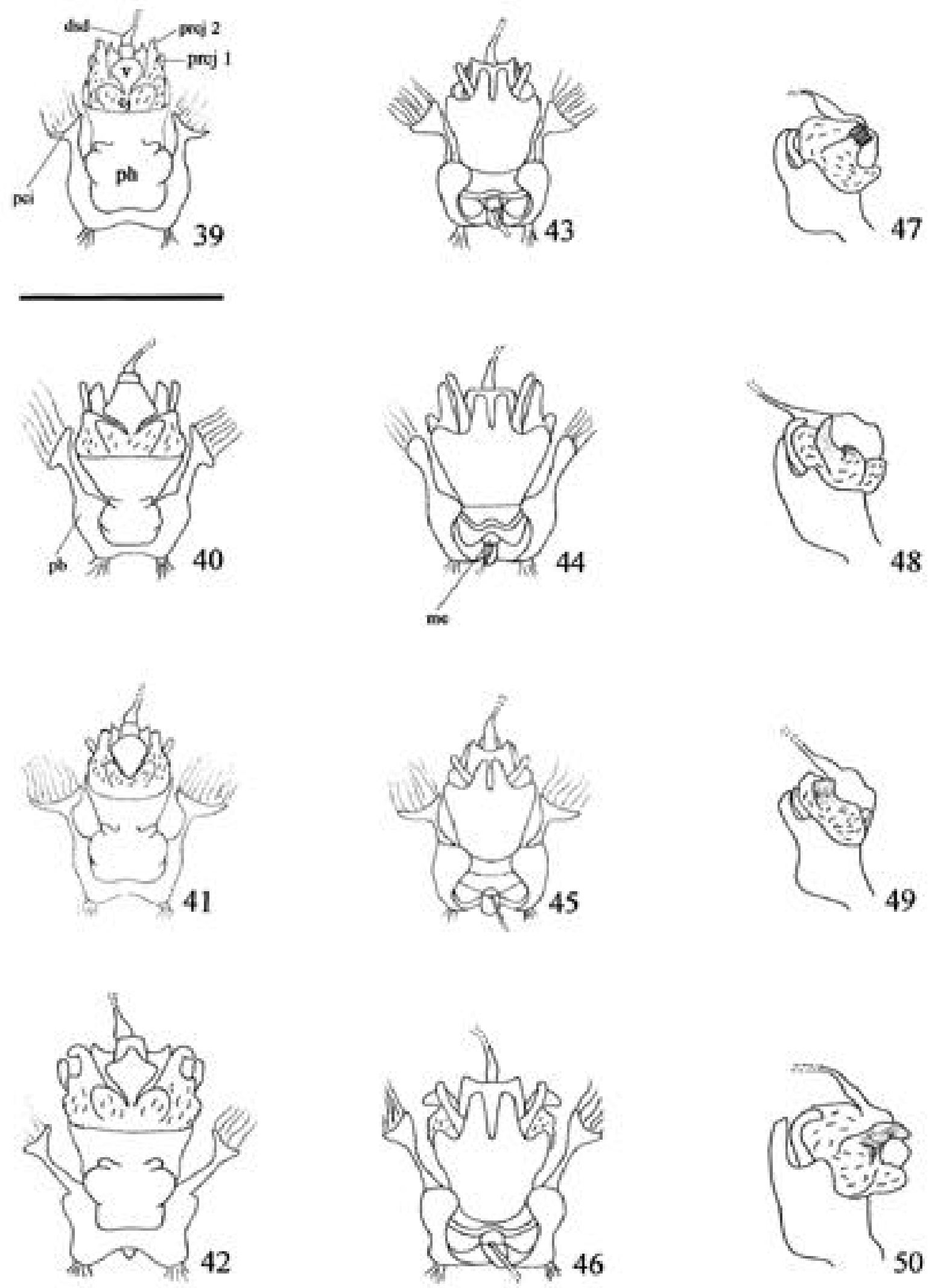

Figs. 39-50. Phallus. 39-42 vista dorsal, 43-46 vista ventral, 47-50 vista lateral, respectivamente. 39, 43, 47, Paramecocephala australis Frey-daSilva \& Grazia sp. nov.; 40, 44, 48, Paramecocephala bergrothi Frey-da-Silva \& Grazia sp. nov.; 41, 45, 49, Paramecocephala subsolana Frey-daSilva \& Grazia sp. nov.; 42, 46, 50, Paramecocephala uruguayensis (Pirán, 1970); cj = conjuntiva; dsd = ductus seminis distalis; me = membramblase; $\mathrm{pb}=$ placa basal $; \mathrm{pci}=$ processus capitati $; \mathrm{ph}=$ phalloteca $;$ prcj $1=$ processus comjuntivae $1 ; \operatorname{prcj} 2=$ processus conjuntivae $2 ; \mathrm{v}=$ vésica $;$ escala $=$ $0,5 \mathrm{~mm}$ 

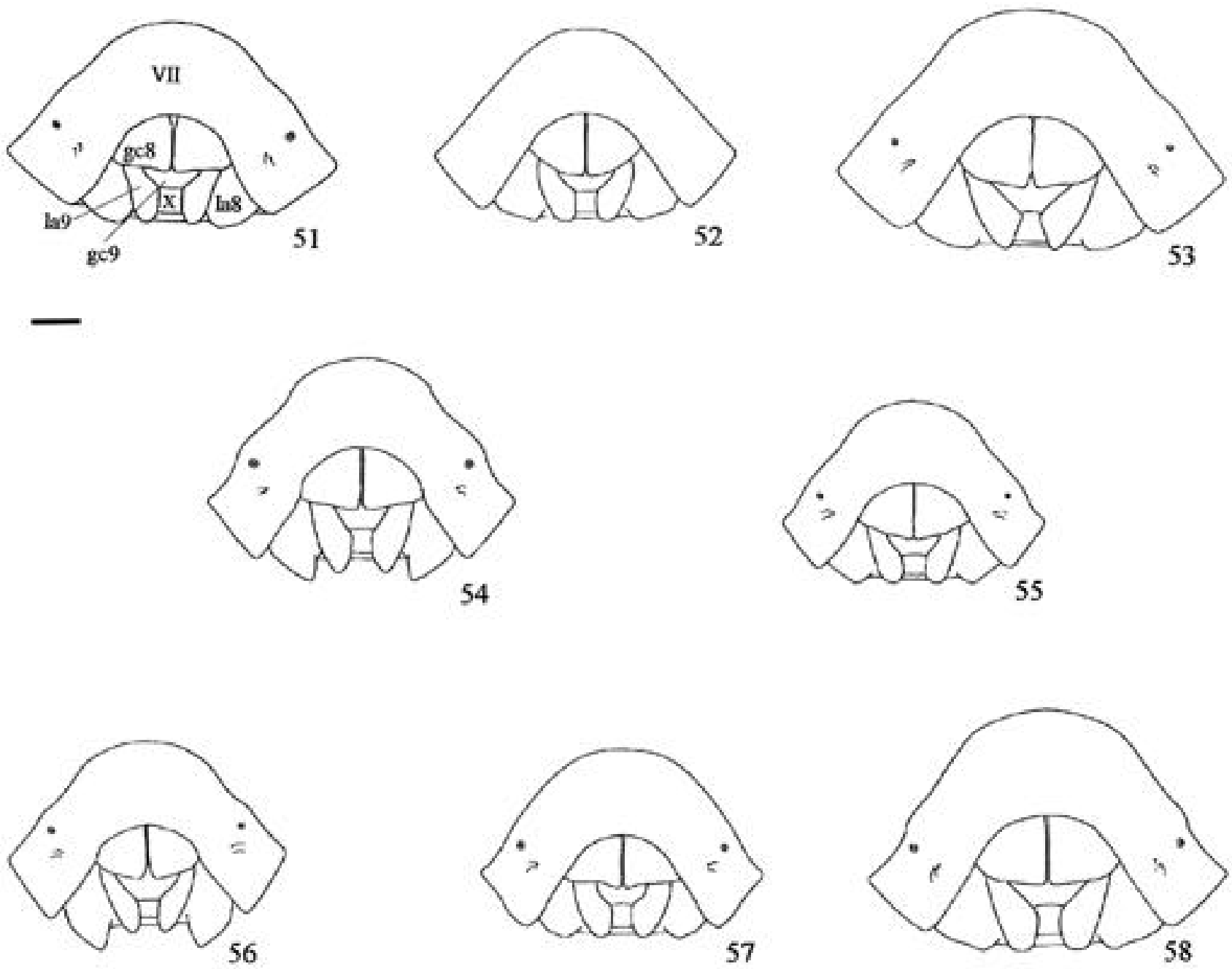

Figs. 51-58. Placas genitais da fêmea, vista ventral. 51, Paramecocephala australis Frey-da-Silva \& Grazia sp. nov.; 52, Paramecocephala bachmanni Frey-da-Silva \& Grazia sp. nov.; 53, Paramecocephala bergrothi Frey-da-Silva \& Grazia sp. nov.; 54, Paramecocephala foveata Benvegnú, 1968; 55, Paramecocephala fusca (Haglund, 1868); 56, Paramecocephala guianensis Frey-da-Silva \& Grazia sp. nov.; 57, Paramecocephala subsolana Frey-da-Silva \& Grazia sp. nov.; 58, Paramecocephala uruguayensis (Pirán, 1970); gc8 = gonocoxitos 8; gc9 = gonocoxitos 9; la8 = laterotergitos 8 ; la9 = laterotergitos 9; VII = sétimo segmento abdominal; $\mathrm{X}=$ décimo segmento; escala $=1 \mathrm{~mm}$.

contrastante, avermelhada.

Genitália. Bordo dorsal do pigóforo (Fig. 13) com 1+1 processos medianos enegrecidos, projetados sobre a base do segmento X. Ângulos póstero-laterais moderadamente escavados, levemente projetados, auriculares. Carena do segmento $X$ subtriangular, não atingindo o ápice do segmento, áreas laterais à carena côncavas, pouco profundas (Fig. 13). Folheto superior do bordo ventral sub-retilíneo medianamente, estruturas globosas com ápice pouco desenvolvido, arredondado, projetado dorsalmente, laterais enegrecidas (Fig. 13). Folheto inferior (Figs. 20, 27, 34) com $1+1$ elevações medianas muito suaves, não formando espinhos, próximas entre si, porém mais afastadas do que em $P$. bachmanni sp. nov. (Fig. 12). Parâmeros pouco visíveis em vista dorsal. Processos ventrais medianos da phalloteca (Fig. 44) levemente divergentes, não recurvados, com o dobro da largura e quase a metade do comprimento dos processus conjuntivae 1 . Processus conjuntivae 1 fortemente recurvados dorsalmente, processus conjuntivae 2 nitidamente tri-ramificado com projeção lateral externa em tubérculo; projeção mediana mais longa, afilada e nitidamente recurvada; projeção externa correspondendo à tumescência da base da vésica, desenvolvida, porém não tanto quanto em $P$. uruguayensis (Figs. 40, 48).

Fêmea semelhante ao macho. Medidas $(\mathrm{n}=10)$ : comprimento total $17,56(16,73-18,86) 0,66$; comprimento total da cabeça 3,13 $(2,84-3,48) 0,22$; largura $2,88(2,75-3,00) 0,08$; comprimento adiante dos olhos $2,05(1,70-2,27) 0,16$; distância interocular $1,80(1,70-1,86) 0,05$; comprimento do pronoto $3,35(2,92-3,65)$ 0,20 ; largura $7,98(7,61-8,34) 0,24$; comprimento do escutelo 6,21 $(5,99-6,56) 0,17$; largura $5,07(4,86-5,43) 0,18$; largura abdominal 

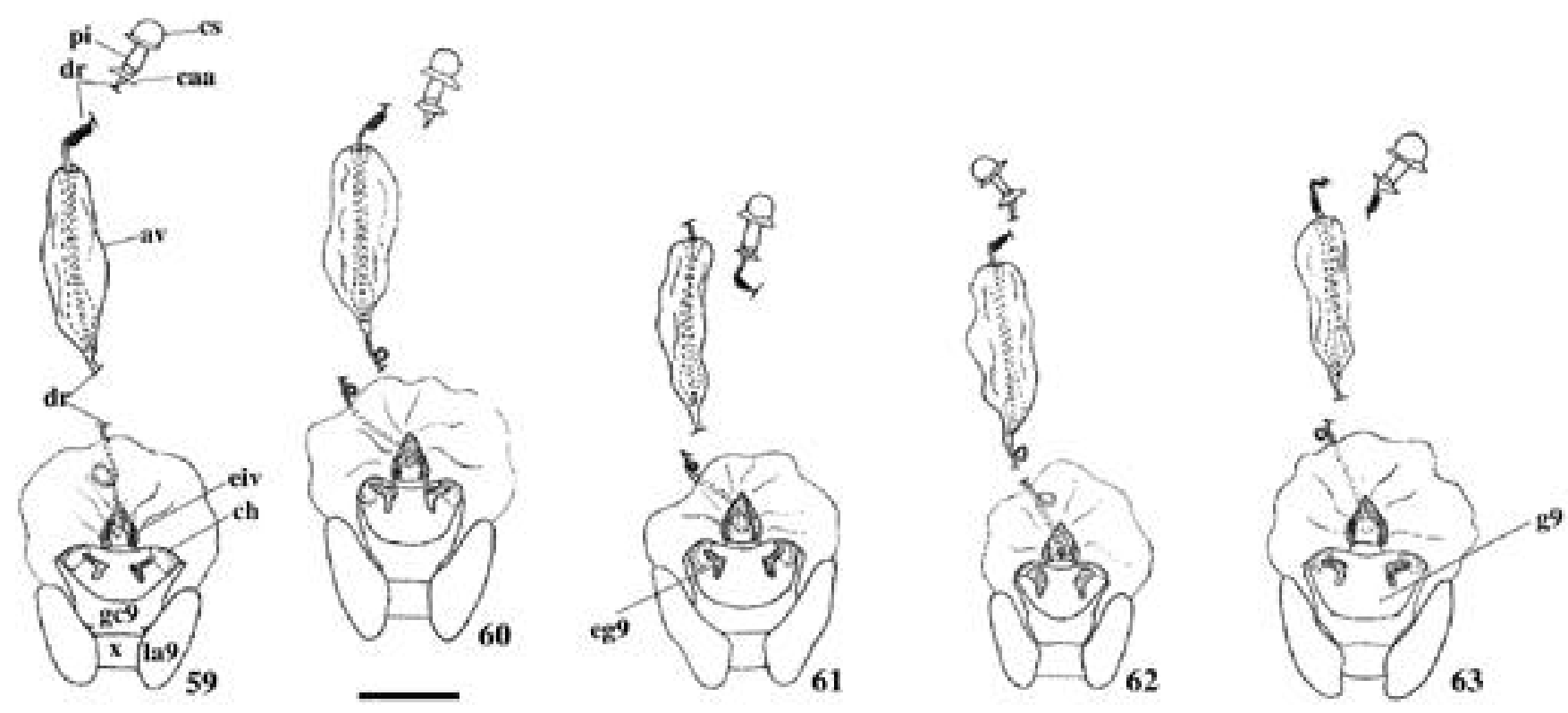

Figs. 59-63. Vias genitais ectodérmicas da fêmea, vista ventral. 59, Paramecocephala australis Frey-da-Silva \& Grazia sp. nov.; 60, Paramecocephala bergrothi Frey-da-Silva \& Grazia sp. nov.; 61, Paramecocephala fusca (Haglund, 1868); 62, Paramecocephala subsolana Frey-da-Silva \& Grazia sp. nov.; 63, Paramecocephala uruguayensis (Pirán, 1970); av = área vesicular; caa = crista anular anterior; ch = chitinellipsen; $\mathrm{cs}=$ capsula seminalis; $\mathrm{dr}=$ ductus receptaculi; eg9 = espessamento das gonopófises $9 ;$ eiv = espessamento da íntima vaginal; g9 = gonapófises $9 ;$ gc $9=$ gonocoxitos 9; la9 = laterotergitos 9; pi = pars intermedialis; $\mathrm{X}=$ décimo segmento; escala $=1 \mathrm{~mm}$.

8,63 (8,10-9,23) 0,36; comprimento do cório 8,38 (7,86-8,75) 0,27; comprimento dos segmentos antenais: I $0,88(0,81-0,97) 0,05$; II $0,58(0,49-0,65) 0,06 ;$ III $1,69(1,54-1,86) 0,10 ;$ IV $1,44(1,38-1,54)$ 0,$06 ; \mathrm{V} 1,86(1,78-1,94) 0,06$.

Genitália (Figs. 53, 60). Gonocoxitos 8 com o bordo posterior levemente côncavo na metade interna e convexo na metade externa. Ângulos suturais arredondados, pouco salientes. Bordos suturais dos gonocoxitos 8 sub-retilíneos, justapostos, ligeiramente divergentes na base e no ápice. Laterotergitos 8 com os bordos posteriores sub-retilíneos, subiguais em comprimento aos laterotergitos 9. Laterotergitos 9 com ápice arredondado, pouco ultrapassando a banda que une dorsalmente os laterotergitos 8 ; margem interna na metade basal retilínea e na metade apical levemente côncava medianamente; margem externa sub-retilínea.

Material-tipo. Holótipo macho. BRASIL. Rio Grande do Sul: Pelotas, 5. V. 1961, C. M. Biezanko leg. (MCNZ). Alótipo fêmea. BRASIL. Rio Grande do Sul: Pelotas, 10. X. 1984, W. Treviso leg. (UFRG). Parátipos. Paraná: Curitiba, 2 machos, 2 fêmeas, IX. 1961, S. Laroca leg., (Barigui), 1 macho, 15. X. 1944, guarda-chuva (DZUP). Santa Catarina: 1 fêmea, Breddin Coll., acuminata Dallas (DEIC). Rio Grande do Sul: Imbé, Albatroz, 1 macho, 6. XII. 1973, R. Wagner Hanisch leg. (UFRG); Porto Alegre: 1 fêmea, 15. X. 1948 (MCNZ); Pelotas, 1 macho, 6. X. 1990, Antonielli leg., 1 macho, 20. IV. 1990, V. Pontes leg., 1 macho, IV. 1985, 1 macho, 10. X. 1960, Irigon leg., 1 macho, IV. 1990, M. H. Tedesco leg. (UFRG), 1 macho (MCNZ, 2803), 1 macho, 15. IV. 1951, C. M. Biezanko leg. (MECB), 1 macho, 12. IV. 1957, C. Biezanko leg. (MACN), 1 fêmea, 10. X. 1981, Treviso leg., 1 fêmea, 4. V-?, M. G. Souza leg., 1 fêmea, 2. X. 1993, P. Timm leg., 1 fêmea, 05. V. 1961, C.
M. Biezanko leg., 1 fêmea, 15. X. 1985, J. Vargas leg., 1 fêmea, 10. X. 1949 (UFRG).

Comentários. Vide comentários em $P$. australis sp. nov. Foi examinado o exemplar macho de Mecocephala rubripes Pirán, 1967 designado como alótipo, o qual, de fato, pertence a essa nova espécie.

\section{Paramecocephala foveata Benvegnú, 1968}

(Figs. 1, 6, 54)

Paramecocephala foveata Benvegnú, 1968: 89.

Macho. Medidas ( $\mathrm{n}=1)$ : comprimento total 13,00; comprimento total da cabeça 2,85; largura 2,50; comprimento adiante dos olhos 1,80; distância interocular 1,80; comprimento do pronoto 2,80; largura 6,65; comprimento do escutelo 4,80; largura 4,40; largura abdominal 7,00; comprimento dos segmentos antenais: I 0,80; II 0,40; III 1,60; os demais faltam (Benvegnú 1968).

Descrição. Cabeça levemente mais longa que larga (Fig. 6), amarelada, pontuação castanha, regularmente distribuída, sendo rara sobre o clípeo. Superfície ventral amarelada a enegrecida, densamente pontuada, pontuação negra. Antenas castanho-amareladas. Rostro amarelado, muito longo, ultrapassando o meio do VII urosternito. Pronoto amarelado, declivente na altura dos úmeros e em direção à cabeça; pontuação castanha. Margens ântero-laterais sub-retilíneas, 
emarginadas e íntegras. Presença de manchas calosas concolores atrás das cicatrizes. Superfície ventral castanha a amarelada, pontuação castanha. Peritrema ostiolar castanhoamarelado. Mesosterno e metasterno castanhos. Pernas amareladas. Ápice do escutelo amarelado; pontos mais confluentes formando dois aglomerados na metade basal e uma linha que se estende desde a base até o ápice do escutelo. Ângulos basais do escutelo com grandes fóveas negras. Ângulos póstero-laterais do cório agudos alcançando a margem posterior do V segmento do conexivo. Mancha calosa do ápice da veia Rádio alongada, esbranquiçada. Sutura da membrana sinuosa. Conexivo amarelado, densamente pontuado, pontuação concolor. Ângulos póstero-laterais pouco pronunciados e arredondados. Superfície ventral do abdome amarelada, pontuação castanha, mais concentrada entre os espiráculos e as margens laterais; estas com pontuação concolor. Sulco mediano abdominal avermelhado alcançando a metade do VII urosternito. Pequenas manchas castanhas nos ângulos ântero-laterais. Espiráculos castanhos. Base dos tricobótrios amarelada.

Genitália. Bordo dorsal do pigóforo destituído de processos medianos. Ângulos póstero-laterais moderadamente escavados, levemente projetados, auriculares. Carena do $\mathrm{X}$ segmento subtriangular, áreas laterais à carena muito pouco profundas; processos dos ângulos basais desenvolvidos, agudos. Folheto superior do bordo ventral sub-retilíneo medianamente, estruturas globosas com ápice agudo. Folheto inferior com elevações medianas quase imperceptíveis. Parâmeros pouco visíveis em vista dorsal. Processos ventrais da phalloteca levemente divergentes e recurvados dorsalmente, arredondados no ápice, mais largos e mais curtos que os processus conjuntivae 1. Processus conjuntivae 1 curvados em direção dorsal; processus conjuntivae 2 digitiformes.

Fêmea semelhante ao macho. Medidas $(\mathrm{n}=1)$ : comprimento total 13,28; comprimento total da cabeça 2,75; largura 2,59; comprimento adiante dos olhos 1,78; distância interocular 1,54; comprimento do pronoto 2,59; largura 6,64; comprimento do escutelo 4,78; largura 4,29; largura abdominal 7,29; comprimento do cório 5,91; comprimento dos segmentos antenais: I 0,65; II 0,49; III 1,70; IV 1,13; V 1,22.

Genitália (Fig. 54). Gonocoxitos 8 com o bordo posterior sub-retilíneo; ângulos suturais arredondados, não salientes. Bordos suturais retilíneos e paralelos. Laterotergitos 8 com os bordos posteriores nitidamente projetados em ângulo agudo, ultrapassando em muito os laterotergitos 9. Laterotergitos 9 espatulares, ápice em ângulo agudo, ultrapassando em muito a banda que une dorsalmente os laterotergitos 8 . Margem interna retilínea na metade basal e levemente convexa e divergente na metade apical; margem externa sub-retilínea.

Material examinado. Holótipo macho. BRASIL. Minas Gerais: Belo Horizonte, 4. XI. 1965, R. Hilbert col. (MCNZ). Parátipo. Mato Grosso: Chapada dos Guimarães, 1 fêmea, 2. II. 1961, J. \& B. Bechyné col. (MPEG).

Comentários. Essa espécie distingue-se das demais pelas fóveas nos ângulos basais do escutelo e rostro muito longo, atingindo o meio do VII urosternito.

\section{Paramecocephala fusca (Haglund, 1868)}

(Figs. 1, 7, 14, 21, 28, 35, 55, 61)

Tibraca fusca Haglund, 1868: 151; Stål, 1872: 30; Lethierry \& Severin, 1893: 132; Kirkaldy, 1909: 72; Barber, 1941: 110; Lima, 1947: 313.

Mecocephala fusca; Fernandes \& Grazia, 1998: 1058

Paramecocephala fusca; Schwertner, Grazia \& Fernandes, 2002:183.

Macho. Medidas $(n=1)$ : comprimento total 11,15; comprimento total da cabeça 2,11; largura 2,03; comprimento adiante dos olhos 1,62; distância interocular 1,22; comprimento do pronoto 2,35; largura 5,75; comprimento do escutelo 3,89; largura 4,05; largura abdominal 5,91; comprimento do cório 5,10; comprimento dos segmentos antenais: I 0,65; II 0,41; III 1,13; os demais faltam.

Descrição. Cabeça mais longa que larga (Fig. 7), castanhoamarelada a amarelada, pontuação negra, sendo mais concentrada sobre as jugas e base da cabeça. Superfície ventral enegrecida, densamente pontuada, pontuação concolor. Antenas castanhas a castanho-escuras. Rostro castanhoamarelado, longo, ultrapassando a margem anterior do V urosternito. Pronoto castanho-amarelado a amarelado, nitidamente em declive na altura dos úmeros e em direção à cabeça. Pontuação negra mais concentrada nos ângulos ânterolaterais e margens ântero-laterais. Margens ântero-laterais levemente côncavas e sutilmente crenuladas no terço basal. Presença de manchas calosas amareladas atrás das cicatrizes. Superfície ventral castanho-amarelada, pontuação negra. Peritrema ostiolar amarelado. Mesosterno e metasterno castanho-avermelhados. Pernas castanho-amareladas. Presença de áreas subcalosas amareladas na base do escutelo. Ângulos póstero-laterais do cório arredondados, ultrapassando a margem anterior do VI segmento do conexivo. Mancha calosa do ápice da veia Rádio esbranquiçada. Sutura da membrana sinuosa. Conexivo concolor, densamente pontuado, pontuação castanha a concolor. Ângulos póstero-laterais arredondados. Superfície ventral do abdome castanho-amarelada a amarelada, pontuação castanho-escura. Sulco mediano abdominal amarelado, alcançando a margem posterior do VI urosternito. Ângulos ântero-laterais com pequenas manchas negras. Espiráculos negros. Base dos tricobótrios amarelada.

Genitália. Bordo dorsal do pigóforo (Fig. 14) côncavo medianamente, não projetado sobre o segmento X. Ângulos póstero-laterais pouco escavados, levemente projetados, auriculares. Carena do X segmento subtriangular, não alcançando o ápice do segmento, processos dos ângulos basais desenvolvidos em ponta romba. Folheto superior do bordo ventral sub-retilíneo medianamente, estruturas globosas quase atingindo a metade do X segmento (Fig. 14), ápice subtruncado. Folheto inferior (Figs. 21, 28, 35) produzido pósteroventralmente com 1+1 elevações formando pequenos espinhos mais afastados entre si do que em P. bachmanni sp. nov. Parâmeros visíveis em vista dorsal, não encobertos pelo ápice 
das estruturas globosas.

Fêmea semelhante ao macho. Medidas $(n=6)$ : comprimento total $12,07(11,15-13,28) 0,77$; comprimento total da cabeça 2,40 (2,27-2,59) 0,12; largura 2,01 (1,38-2,35) 0,37; comprimento adiante dos olhos $1,57(1,38-1,78) 0,17$; distância interocular $1,44(1,22-2,11) 0,38$; comprimento do pronoto $2,38(2,11-2,67)$ 0,25 ; largura $6,12(5,67-6,72) 0,39$; comprimento do escutelo 4,24 $(3,97-4,70) 0,27$; largura 3,90 (3,56-4,21) 0,26; largura abdominal 6,29 (5,67-7,05) 0,49; comprimento do cório 5,44 (4,94-6,08) 0,41; comprimento dos segmentos antenais: I 0,60 (0,57-0,65) 0,04; II $0,45(0,41-0,49) 0,04$; III 1,22 (1,13-1,38) 0,11; IV 1,03 (0,97-1,05) 0,05; V 1,27 (1,22-1,30) 0,05.

Genitália (Figs. 55, 61). Gonocoxitos 8 com o bordo posterior sinuoso; ângulos suturais arredondados, não salientes. Bordos suturais dos gonocoxitos 8 sub-retilíneos e justapostos. Laterotergitos $8 \mathrm{com}$ os bordos posteriores em ângulo reto, pouco ultrapassando em comprimento os laterotergitos 9 . Laterotergitos 9 espatulares, ápice arredondado, ultrapassando levemente a banda que une dorsalmente os laterotergitos 8 . Margem interna sutilmente côncava na metade basal e retilínea na metade apical; margem externa sub-retilínea.

Material examinado. Holótipo macho. BRASIL ?, M. [useum] berl. [inensis], Typus (NHRS). SURINAME: 1 fêmea, P. H. v. Doesburg Jr. leg. (RMNH). EQUADOR. Napo: Lago Agrio $(18 \mathrm{Km}), 1$ fêmea, EcuadorPeace Corps - Smithsonian Institution Aquatic Insect Survey, "ex. oil palm with marchitez", A. Langley leg. (USNM); Coca, 1 fêmea, IV. 1985, G. Onore leg.(MZSP). BRASIL. Amazonas: Rio Itacoari,1 fêmea, VI. 1950, J. C. M. Carvalho leg. (MNRJ); Benjamin Constant, 1 fêmea, XI. 1962, A. Silva leg.; Pará: 1 fêmea, I. 1997 (UFRG).

Comentários. Essa espécie, pelo porte, aproxima-se de $P$. guianensis sp. nov. Em $P$. fusca, a coloração geral do corpo é castanho-amarelada e as margens ântero-laterais do pronoto sutilmente côncavas; em $P$. guianensis sp. nov., a coloração geral do corpo é castanho-avermelhada a castanho-escura e as margens ântero-laterais do pronoto, sub-retilíneas. Distinguemse ainda pela distância entre os espinhos do folheto inferior do bordo ventral do pigóforo: em $P$. fusca, a distância entre eles é igual à largura do segmento $\mathrm{X}$, enquanto em $P$. guianensis $\mathbf{s p}$. nov. os espinhos estão mais próximos entre si, numa distância igual à metade da largura do $\mathrm{X}$ segmento. As fêmeas também se distinguem facilmente pela projeção do bordo posterior dos laterotergitos 8; em $P$. fusca, os laterotergitos 8 pouco ultrapassam os laterotergitos 9 e em $P$. guianensis sp. nov. os laterotergitos 8 ultrapassam em muito os laterotergitos 9 .

Paramecocephala guianensis Frey-da-Silva \& Grazia, sp. nov. (Figs. 1, 8, 15, 22, 29, 36, 56)

Etimologia. O nome da espécie é alusivo à distribuição geográfica.

Macho. Medidas $(n=1)$ : comprimento total 11,15; comprimento total da cabeça 2,51; largura 2,19; comprimento adiante dos olhos 1,86; distância interocular 1,30; comprimento do pronoto 1,94 ; largura 5,35; comprimento do escutelo 4,05; largura 3,48; largura abdominal 5,59; comprimento do cório 5,27; comprimento dos segmentos antenais: I 0,57; II 0,49; III 1,38; IV 0,89; V 0,97.

Descrição. Cabeça mais longa que larga (Fig. 8), castanhoavermelhada a castanho-escura, pontuação negra, mais concentrada e confluente sobre as jugas. Clípeo nitidamente mais elevado em relação às jugas. Superfície ventral negra, densamente pontuada, pontuação concolor. Margens laterais das jugas castanho-avermelhadas. Antenas castanhas. Rostro vermelho-alaranjado, longo, ultrapassando a margem posterior do V urosternito. Pronoto castanho-avermelhado, pouco declivente na altura dos úmeros em direção à cabeça. Pontuação profunda e confluente no terço anterior às cicatrizes e nas margens ântero-laterais. Margens ântero-laterais sub-retilíneas, levemente enrugadas junto aos ângulos ântero-laterais. Áreas subcalosas amareladas próximas às cicatrizes. Superfície ventral castanho-avermelhada a castanho-escura com densa pontuação negra. Margem lateral da propleura, mesopleura e pequena área subcalosa na margem lateral da metapleura avermelhadas. Peritrema ostiolar castanho-avermelhado. Mesosterno e metasterno avermelhados. Pernas vermelhoalaranjadas. Presença de manchas calosas amareladas na base do escutelo, junto às fóveas. Ângulos póstero-laterais do cório agudos, alcançando a metade do VI segmento do conexivo. Mancha calosa do ápice da veia Rádio arredondada, pequena e esbranquiçada. Sutura da membrana sub-retilínea. Conexivo castanho-escuro a castanho-avermelhado na metade interna, pontuação densa, concolor. Superfície ventral do abdome castanho-avermelhada. Sulco mediano abdominal vermelhocobre, alcançando o VI urosternito. Espiráculos negros. Base dos tricobótrios avermelhada.

Genitália. Bordo dorsal do pigóforo (Fig. 15) sub-retilíneo, não projetado sobre o segmento X. Ângulos póstero-laterais pouco escavados, arredondados. Segmento X com a superfície dorsal côncava, com carena basal em "u". Folheto superior do bordo ventral sub-retilíneo medianamente, estruturas globosas amplamente arredondadas (Fig. 15), ápice arredondado. Folheto inferior fortemente produzido póstero-ventralmente com 1+1 elevações formando pequenos espinhos muito próximos entre si (Figs. 22, 29, 36). Parâmeros não visíveis em vista dorsal.

Fêmea semelhante ao macho. Medidas $(\mathrm{n}=1)$ : comprimento total 12,46; comprimento total da cabeça 2,67; largura 2,19; comprimento adiante dos olhos 1,70; distância interocular 1,30; comprimento do pronoto 2,27; largura 5,83; comprimento do escutelo 4,21; largura 3,73; largura abdominal 6,24; comprimento do cório 5,91; comprimento dos segmentos antenais: I 0,65; II 0,57; III 1,46; os demais faltam.

Genitália (Fig. 56). Gonocoxitos 8 com o bordo posterior levemente sinuoso; ângulos suturais arredondados, pouco desenvolvidos. Bordos suturais dos gonocoxitos 8 subparalelos, divergentes no terço apical. Bordo posterior dos laterotergitos 8 nitidamente projetados em ângulo agudo, ultrapassando em muito os laterotergitos 9. Laterotergitos 9 estreitos, espatulares, com ápice arredondado, nitidamente ultrapassando a banda que une dorsalmente os laterotergitos 
8. Margem lateral interna com metade basal levemente côncava e metade apical levemente convexa; margem externa subretilínea.

Material-tipo. Holótipo macho. GUIANA FRANCESA: Montsinéry, San Bordelaise, 4. VII. 1977, Rémillet leg., ORSTOM (MNHN). Alótipo fêmea. GUIANA: Rupununi, Savannahs, 1922, J. G. Myers leg. (BMNH).

Comentários. Vide comentários sobre P. fusca.

Paramecocephala subsolana Frey-da-Silva \& Grazia, sp. nov. (Figs. 1, 9, 16, 23, 30, 37, 41, 45, 49, 57, 62)

Etimologia. O nome dessa espécie é alusivo à distribuição geográfica atual desta espécie, visto que o material tipo foi coletado no leste do Brasil. (subsolana=região leste).

Macho. Medidas (n=2): comprimento total 11,81 $(11,67-$ $11,97) 0,23$; comprimento total da cabeça $2,55(2,51-2,59) 0,06$; largura 2,31 (2,27-2,35) 0,06; comprimento adiante dos olhos 1,66 (1,62-1,70) 0,06; distância interocular 1,38 (1,30-1,46) 0,11; comprimento do pronoto $2,43(2,35-2,51) 0,11$; largura $6,08(5,75$ 6,40) 0,46; comprimento do escutelo $4,29(4,05-4,54) 0,34$; largura $3,85(3,65-4,05) 0,29$; largura abdominal 6,28 (6,08-6,48) 0,29; comprimento do cório 5,59 (5,27-5,91) 0,46; comprimento dos segmentos antenais: I $0,77(0,65-0,89) 0,17$; II $0,53(0,49-0,57)$ 0,06; III 1,13; IV 1,09 (1,05-1,13) 0,06; V 1,46 (1,38-1,54) 0,11.

Descrição. Cabeça mais longa que larga (Fig. 9), castanhoamarelada, pontuação densa e negra. Superfície ventral castanho-amarelada, pontuação densa e negra. Antenas castanho-avermelhadas a castanho-amareladas. Rostro castanho-amarelado alcançando a metade do VI urosternito. Pronoto castanho-amarelado com o terço anterior em declive; pontuação densa e negra. Margens ântero-laterais levemente convexas, crenuladas no terço basal. Superfície ventral castanho-amarelada com pontuação densa, enegrecida, com uma faixa negra delimitando o pronoto ventral da propleura. Mesosterno e metasterno enegrecidos. Ruga ostiolar amarelada. Pernas alaranjadas. Ângulos póstero-laterais do cório arredondados, ultrapassando a margem posterior do $\mathrm{V}$ segmento do conexivo. Mancha calosa do ápice da veia Rádio esbranquiçada a amarelada. Sutura da membrana sinuosa. Conexivo castanho-amarelado, pontuação castanha a concolor. Superfície ventral do abdome castanho-amarelada; pontuação densa, enegrecida. Margens laterais do abdome amareladas, pontuação concolor. Sulco mediano abdominal amarelado alcançando a metade do VI urosternito. Ângulos ântero-laterais com pequenas manchas castanhas. Espiráculos negros. Base dos tricobótrios amarelada.

Genitália. Bordo dorsal do pigóforo (Fig. 16) levemente côncavo no terço mediano, terço lateral com um processo enegrecido mais próximo dos ângulos póstero-laterais, esses moderadamente escavados. Carena do X segmento subtriangular, não atingindo o ápice do segmento, áreas laterais à carena profundamente côncavas, processos dos ângulos basais desenvolvidos, agudos. Folheto superior do bordo ventral do pigóforo sub-retilíneo medianamente, estruturas globosas (Fig. 16) com ápice subtruncado (Figs. 23, 30, 37). Folheto inferior levemente escavado medianamente em "v" aberto, destituído de projeções espiniformes. Pârameros visíveis em vista dorsal. Processos ventrais da phalloteca (Fig. 45) convergentes apicalmente, levemente curvados dorsalmente, ápice arredondado, largura igual a duas vezes a largura dos processus conjuntivae 1; ângulos póstero-laterais da phalloteca pouco desenvolvidos. Processus conjuntivae 1 pouco curvados dorsalmente; processus conjuntivae 2 direcionados posteriormente, espatulares, superfície com ranhuras, ápice truncado (Figs. 41, 49).

Fêmea semelhante ao macho. Medidas ( $\mathrm{n}=2)$ : comprimento total 13,94 (13,45-14,43) 0,70; comprimento total da cabeça 2,88 $(2,83-2,92) 0,06$; largura 2,43; comprimento adiante dos olhos 2,03; distância interocular 1,54; comprimento do pronoto 2,63 $(2,43-2,83) 0,29$; largura 6,64 (6,56-6,72) 0,11 ; comprimento do escutelo 4,70 $(4,62-4,78) 0,11$; largura 4,25 (4,22-4,30) 0,06; largura abdominal 7,05 (6,80-7,29) 0,34; comprimento do cório 6,08 $(5,75$ $6,40) 0,46$; comprimento dos segmentos antenais: I 0,77 $(0,73-$ $0,81) 0,06$; II 0,57; III 1,26 (1,21-1,30) 0,06; IV 1,13; o quinto falta.

Genitália (Figs. 57, 62). Gonocoxitos 8 com o bordo posterior levemente côncavo medianamente; ângulos suturais arredondados e levemente produzidos sobre os gonocoxitos 9. Bordos suturais dos gonocoxitos 8 paralelos e sub-retilíneos. Laterotergitos $8 \mathrm{com}$ os bordos posteriores em ângulo reto, ápice arredondado, pouco mais longos que os laterotergitos 9. Laterotergitos 9 com ápice arredondado, pouco ultrapassando a banda que une dorsalmente os laterotergitos 8. Margem interna com metade basal côncava e metade apical sub-retilínea, divergentes no ápice; margem externa convexa.

Material-tipo. Holótipo macho. BRASIL. Bahia: Maracás, 18. VIII. 1964, C. Elias leg. (DZUP). Alótipo fêmea. São Paulo: São Paulo, 5. X. 1965, V. N. Alin leg. (USNM). Parátipos. Espírito Santo: Santa Tereza, 1 macho [s/ pigóforo], 6. VII. 1964 (USNM); 1 fêmea, 13. V. 1964 (UFRG).

Comentários. Vide comentários sobre P. bachmanni sp. nov.

Paramecocephala uruguayensis (Pirán, 1970)

(Figs. 1, 10, 17, 24, 31, 38, 42, 46, 50, 58, 63)

Mecocephala uruguayensis Pirán, 1970: 124, lam.II, figs 1, 2.

Paramecocephala uruguayensis; Schwertner, Grazia \& Fernandes, 2002:183.

Macho. Medidas ( $\mathrm{n}=18)$ : comprimento total 16,83 (15,20$18,20) 0,87$; comprimento total da cabeça $3,24(2,88-3,52) 0,16$; largura 3,02 (2,80-3,20) 0,10 ; comprimento adiante dos olhos 2,07 (1,68-2,32) 0,19; distância interocular 1,91 (1,76-2,08) 0,10; comprimento do pronoto $3,19(2,80-3,36) 0,23$; largura $7,97(7,28$ $8,40) 0,47$; comprimento do escutelo $5,97(5,52-6,24) 0,32$; largura $5,22(4,56-5,76) 0,54$; largura abdominal $8,27(7,44-8,64) 0,51$; comprimento do cório $7,94(7,28-8,56) 0,42$; comprimento dos segmentos antenais: I 0,90 (0,72-1,04) 0,07 ; II 0,57 $(0,48-0,64)$ 0,07 ; III 1,73 (1,52-1,84) 0,10; IV 1,51 (1,36-1,52) 0,06; V 1,81 
(1,68-1,92) 0,08.

Descrição. Cabeça levemente mais longa que larga (Fig. 10), castanho-avermelhada a castanho-amarelada; pontuação densa e negra. Superfície ventral da cabeça castanho-escura a castanho-avermelhada, pontuação densa e negra. Antenas castanho-avermelhadas. Rostro castanho-avermelhado ultrapassando a margem posterior do V urosternito. Pronoto castanho-amarelado, pouco declivente na altura dos úmeros em direção a cabeça. Margens ântero-laterais côncavas; terço basal levemente crenulado e enrugado. Presença de manchas calosas amareladas atrás das cicatrizes. Superfície ventral castanho-amarelada a castanho-avermelhada; pontuação densa e negra. Mesosterno e metasterno negros. Peritrema ostiolar alaranjado. Pernas castanho-avermelhadas. Ângulos pósterolaterais do cório agudos, alcançando o $6^{\circ}$ segmento do conexivo. Mancha calosa do ápice da veia Rádio pequena, esbranquiçada. Sutura da membrana sinuosa. Conexivo castanho-amarelado com densa pontuação, pontos castanhos a concolores. Superfície ventral do abdome castanho-escura a castanho-avermelhada; pontos castanhos, menores que os do pronoto ventral. Margens laterais do abdome e sulco mediano abdominal amarelados, esse, alcançando o $6^{\circ}$ segmento abdominal; margens laterais com pontuação castanha. Pequenas manchas semi-circulares castanho-escuras nos ângulos ântero-laterais do III ao VII segmento abdominal. Espiráculos negros. Base dos tricobótrios castanho-amarelada.

Genitália. Bordo dorsal do pigóforo (Fig. 17) côncavo medianamente, terços laterais com um processo junto aos ângulos póstero-laterais, estes escavados, levemente produzidos, arredondados. Folheto superior do bordo ventral do pigóforo sub-retilíneo medianamente, estruturas globosas com ápice afilados voltados lateralmente (Fig. 17). Folheto inferior (Figs. 24, 31, 38) com 1+1 projeções em pequeníssimos espinhos, distanciados entre si tanto quanto em $P$. bergrothi sp. nov. e em $P$. fusca. Carena do segmento X subtriangular, áreas laterais à carena côncavas, pouco profundas, processos dos ângulos basais desenvolvidos, agudos. Parâmeros pouco visíveis, dorsalmente encobertos pelas estruturas globosas. Processos ventrais da phalloteca (Fig. 46) subparalelos, ápice subtruncado, não recurvado, com o dobro da largura e muito mais curtos do que os processus conjuntivae 1. Processus conjuntivae 1 fortemente recurvados dorsalmente; processus conjuntivae 2 muito desenvolvidos, nitidamente tri-ramificados e recurvados no ápice, sendo a projeção mediana mais longa e afilada, projeção lateral externa formando um tubérculo, projeção interna correspondendo à tumescência da base da vésica, nitidamente mais desenvolvida nesta espécie que nas demais (Figs. 42, 50)

Fêmea semelhante ao macho. Medidas $(\mathrm{n}=12)$ : comprimento total $17,98(16,70-19,37) 0,82$; comprimento total da cabeça 3,25 $(3,12-3,52) 0,14$; largura $2,95(2,80-3,12) 0,12$; comprimento adiante dos olhos 2,06 (1,76-2,32) 0,14; distância interocular $1,94(1,68-2,08) 0,12$; comprimento do pronoto $3,23(2,64-3,60)$ 0,28 ; largura $7,77(7,28-8,56) 0,47$; comprimento do escutelo 6,16 $(5,84-6,72) 0,26$; largura 4,97 (4,64-5,28) 0,25; largura abdominal
8,53 (7,84-9,60) 0,53; comprimento do cório 8,10 (7,52-8,80) 0,43; comprimento dos segmentos antenais: I $0,87(0,80-0,96) 0,06$; II $0,60(0,40-0,80) 0,11$; III 1,67 (1,52-1,76) 0,11; IV 1,45 (1,36-1,60) 0,$09 ; \mathrm{V} 1,76(1,60-1,92) 0,10$.

Genitália (Figs. 58, 63). Gonocoxitos 8 com os bordos posteriores sub-retilíneos a levemente convexos no terço externo; ângulos suturais arredondados, não salientes. Bordos suturais dos gonocoxitos 8 sub-retilíneos e paralelos. Laterotergitos 8 com os bordos posteriores sinuosos; ápice arredondado. Laterotergitos 8 subiguais em comprimento aos laterotergitos 9. Laterotergitos 9 com ápice subtruncado, ultrapassando levemente a banda que une dorsalmente os laterotergitos 8. Margem interna na metade apical sub-retilínea a divergente no ápice; margem externa sub-retilínea.

Material examinado. Holótipo macho. URUGUAI. Montevideo: Santiago Vazquez, Parque Lecoq, 15. III. 1960, C. S. Morey leg., Coll. Pirán (MACN). Alótipo fêmea. URUGUAI. Artigas: Arroyo Tres Cruces, 22. IX. 1957, Sociedad Taguató leg., Pirán coll. (MACN). Parátipos. ARGENTINA. Buenos Aires: Quequen-Salado, 1 macho, 2 fêmeas, X. 1969, A. A. Pirán leg.; 8 machos, 3 fêmeas, 39246; 5 machos, 2 fêmeas, J. Daguerre leg.; 2 machos, 1 fêmea, VIII. 1959, Faculdad Ch de Coria, Insectario "s/ cortadera"; 1 fêmea, 10517; 1 macho, 31058. Corrientes: San Tome, 1 macho, VI. 1923 (MACN). URUGUAI. Montevideo: Sgo. Vazquez, 1 fêmea, 2. X. 1960 (UFRG); Atlântida, 1 fêmea, 28. VII. 1997 (MACN). 1 fêmea sem dados (UFRG), 1 fêmea [11949], sem dados (MACN).

Comentários. Vide comentários sobre P. australis sp. nov.

Agradecimentos. Aos curadores das coleções que enviaram materialtipo e exemplares para o desenvolvimento deste trabalho.

\section{REFERÊNCIAS}

Amorim, D. S. \& M. R. S. Pires. 1996. Neotropical biogeography and a method for maximum biodiversity estimation, p. 183-219. In: C. E. M. Bicudo \& N. A. Menezes (eds.). Biodiversity in Brazil, a first approach. São Paulo, CNPq, 326p.

Arnett, R. H. Jr; G. A. SAmuelson \& G. M. Nishida. 1993. The insects and spiders collections of the World. Gainesville, E. J. Briel/Flora \& Fauna publications, 309p.

BARBER, H. G. 1941. A new species of Tibraca, injurious to rice in Ecuador (Hemiptera-Heteroptera: Pentatomidae). Proceedings of the Entomological Society of Washington 43:110.

Benvegnú, G. Q. 1968. Paramecocephala, um novo gênero de Pentatomini do Brasil (Hemiptera, Pentatomidae, Pentatominae). Revista Brasileira de Biologia 28(1):87-96.

BERG, C. 1894. Hemipteros - Heteropteros nuevos o poco conocidos. Anales del Museo National de Montevideo 1:18.

Dallas, W. S. 1851. List of the specimens of Hemipterous insects in the collection of the British Museum. London. I. 390p. 15 pls.

Dupuis, C. 1970. Heteroptera, p. 190-208. In: S.L. TUXEN (Ed.) Taxonomist's glossary of genitalia of insects. Copenhagen, Munskgaard, 359p.

Fernandes, J. A. M. \& J. Grazia. 1998. Revision of the genus Tibraca Stål, 1860 (Heteroptera: Pentatomidae: Pentatomini). Revista Brasileira de Zoologia 15(4):1049-1060.

Grazia, J.; J. A. M. Fernandes \& C.F. Schwertner. 1999. Stysiana, a new genus and four new species of Pentatomini (Heteroptera, Pentatomidae) of the Neotropical region. Acta Societatis Zoologicae 63:71-83. 
Haglund, E. J. C. 1868. Hemiptera Nova. Stettiner entomologische Zeitung 29:150-163.

Kirkaldy, G. W. 1909. Catalogue of the Hemiptera (Heteroptera). 1- Cimicidae. Berlin, Felix L. Dames. xl + 392p.

Lethierry, L. \& G. Severin. 1893. Catalogue Général des Hemiptéres. Pentatomidae. Bruxelles, Mus. R. Hist. Nat. Belgique, $x+286$ p.

Lima, A. M. da C. 1947. Notas sobre alguns pentatomídeos. Anais da Academia Brasileira de Ciências 19(4):311-313.

MAYR, G. L. 1864. Diagnosen neuer Hemipteren. Verhandlungen der zoologisch-Botanischen Gesellschaft in Wien. 14: 903-914.

Pirán, A. A. 1967. Hemiptera Neotropica XI. Revista de la Sociedad
Entomologica Argentina 30(1-4):17-25.

Pirán, A. A. 1970. Hemiptera Neotropica XIII. Acta Zoologica Lilloana 26(8): 124-126.

Schwertner, C. F.; J. Grazia \& J. A. M. Fernandes 2002. Revisão do gênero Mecocephala Dallas, 1851 (Heteroptera, Pentatomidae). Revista Brasileira de Entomologia 46(2):169-183.

STÅL, C. 1860. Bidrag till Rio de Janeiro - traktens Hemipter - fauna. Kongliga Svenska Vetenskaps-Akademiens Handlingar 2(7): $1-84$.

STÅL, C. 1872. Enumeratio Hemipterorum II. Kongliga Svenska Vetenskaps-Akademiens Handlingar 10(4):1-159. 